\title{
Crystal Clear? The Relationship between Methamphetamine Use and Risky Sexual Behavior
}

\author{
Hugo M. Mialon, Erik T. Nesson, and Michael C. Samuel ${ }^{*}$
}

March 2013

\begin{abstract}
We estimate the effect of methamphetamine use on risky sexual behavior using California data on amphetamine-related hospital admissions and syphilis diagnoses from 1994 to 2000. Public health officials have cited methamphetamine control as a tool with which to decrease sexually transmitted infections, based on previous research that finds a strong positive correlation between methamphetamine use and risky sexual behavior. However, the observed correlation may not be causal, as both methamphetamine use and risky sexual behavior could be driven by a third factor, such as a preference for risky behavior. To circumvent this possible endogeneity, we use a large exogenous supply shock in the U.S. methamphetamine market that occurred in mid-1995 and a later supply shock stemming from the 1996 Methamphetamine Control Act. While we find that the supply shocks had large negative effects on methamphetamine use, we find no evidence that these decreases in methamphetamine use decreased syphilis rates.
\end{abstract}

JEL Codes: I18, I12, K14, K42

Keywords: Supply Shock, Ephedrine, Methamphetamine, Substance Use, Syphilis, Risky Sexual Behavior, Sexually Transmitted Diseases, Sexually Transmitted Infections, STD, STI.

\footnotetext{
* Hugo M. Mialon, Department of Economics, Emory University, Atlanta, GA 30322 (hmialon@emory.edu); Erik T. Nesson, Department of Economics, Ball State University, Muncie, IN 47306 (etnesson@bsu.edu); Michael C. Samuel, Surveillance and Epidemiology Section, STD Control Branch, California Department of Public Health (Michael.Samuel@cdph.ca.gov).
} 


\section{Introduction}

Risky sexual behavior and sexually transmitted infections (STIs) constitute a major health problem in the United States. According to the Centers for Disease Control and Prevention (CDC), there are about 19 million new STIs each year, costing the healthcare system \$16.4 billion annually. Previous research suggests a high degree of correlation between methamphetamine use and the incidence of STIs (Molitor et al. 1998; Molitor et al. 1999; Halkitis, Parsons and Stirratt 2001; Shoptaw and Reback 2007; Taylor et al. 2007), and public health officials have increasingly targeted rising methamphetamine use as a factor in increasing STI rates. ${ }^{1}$ However, drawing a causal inference from this correlation is difficult, as a third factor, perhaps a preference for risky behavior, might drive both methamphetamine use and risky sexual behavior. Determining causality is important, since if the relationship between methamphetamine use and risky sexual behavior is not causal, policies to reduce methamphetamine use may not reduce risky sexual behavior and STI prevalence.

The goal of this paper is to determine whether there is a causal relationship between methamphetamine use and risky sexual behavior. To circumvent the potential problem of omitted variable bias, we use supply shocks in the methamphetamine market as instrumental variables for methamphetamine use in two-stage-least-squares estimation. In our main analysis, we examine the period from 1994 to 1997 and use a supply shock arising from the closure by the Drug Enforcement Agency (DEA) of two pharmaceutical companies in May 1995. These two pharmaceutical companies had been supplying more than 50 percent of the pseudoephedrine used in the U.S. methamphetamine market. Previous papers examining this supply shock find that it increased methamphetamine prices from $\$ 30$ per gram to $\$ 100$ per gram and decreased the

\footnotetext{
${ }^{1}$ See, for example, http://www.cdc.gov/hiv/resources/factsheets/meth.htm (accessed March, 2013).
} 
substance's purity from 90 percent to 20 percent (Dobkin and Nicosia 2009), causing amphetamine-related hospital admissions to drop by 30 to 50 percent (Cunningham and Liu 2003; Dobkin and Nicosia 2009).

We start by re-examining the effect of the 1995 supply shock on methamphetamine consumption, using amphetamine-related hospital admissions from the California Office of Statewide Health Planning and Development (OSHPD) to proxy for methamphetamine use. Similar to previous studies examining the effect of the 1995 shock on methamphetamine use, we find that the shock reduced amphetamine-related hospitalizations by 30 percent during the period of August 1995 to September 1996. Next, we examine the dynamic effects of the supply shock. We find that the first two months of the shock caused a 25 percent decrease in amphetaminerelated hospital admissions. In the following three months, the shock reduced the admissions rate by 41 percent, and in the last three months of the shock, the admissions rate fell by 22 percent.

We then turn to estimating the causal impact of methamphetamine use on risky sexual behavior, using the supply shock as an instrument for methamphetamine consumption and using monthly county-level early-stage syphilis reports in California from the California Department of Public Health (CDPH) to measure risky sexual behavior. We find no evidence of a positive effect of methamphetamine use on syphilis rates. Our estimate of the elasticity of syphilis rates with respect to methamphetamine use is -0.23 . Broken down by gender, we find some evidence that the supply shock increased the syphilis rate in women, although this effect is not present in all specifications.

In additional analysis, we examine the period from 1997 to 2000 and use a shock to the methamphetamine market arising from the Methamphetamine Control Act (MCA) signed into 
law by President Clinton in October 1996. In addition to measures designed to combat the manufacture of methamphetamine in Mexico for import into the United States, starting in October 1997, the MCA limited the quantities of pseudoephedrine that could be sold to consumers and placed additional requirements on manufacturers, distributors, and sellers of pseudoephedrine and other methamphetamine precursors.

We find that the October 1997 shock reduced amphetamine-related hospitalizations by roughly 15 percent during the period of April 1998 to March 1999. Examining the dynamics of this second shock, we find that the largest reductions occurred in late 1998 to early 1999, with a 30 percent reduction in amphetamine-related hospitalizations between October 1998 and January 1999. Unlike the 1995 supply shock, the effects of the MCA lasted much longer. Amphetaminerelated hospital admissions were still 25 percent lower than their pre-shock value after June 1999. However, as with the 1995 shock, we find little evidence that amphetamine-related hospitalizations are statistically related to syphilis diagnoses when using the MCA shock as an instrument.

Our paper makes several contributions to the literature examining substance use and risky sexual behavior. First, it is the first paper to estimate a causal relationship between methamphetamine use and risky sexual behavior. Second, it is the first paper to use a supply shock to estimate a causal relationship between substance use and risky sexual behavior. Other papers estimate the effects of supply shocks on substance use or use supply shocks to measure the effects of substance use on other negative social outcomes such as crime and foster care (Dobkin and Nicosia 2009; Anderson 2010; Cunningham and Finlay 2011; Nonnemaker, Engelen and Shive 2011). We believe this identification strategy is well suited to estimating a relationship between substance use and risky sexual behavior and STIs. Our paper joins other 
economics papers that estimate causal relationships between substance use and risky sexual behavior using substance prices and taxes in reduced form specifications (Grossman, Kaestner and Markowitz 2004; Grossman and Markowitz 2005). However, our identification strategy provides advantages over using prices as a measure of substance use. We are able to measure substance use at the county and month level, providing more data variation than previous studies. Moreover, the 1995 supply shock (and to a lesser extent the 1997 supply shock) that we use in our instrumental variable analysis is an exogenous shifter of the methamphetamine supply curve without the endogeneity concerns arising from the use of prices as instrumental variables. Lastly, we decompose the dynamic effects of the supply shock on methamphetamine consumption. This decomposition allows us to determine the periods in which the supply shocks had the largest effects on methamphetamine consumption.

The remainder of the paper is laid out as follows. Section II provides background on methamphetamine and risky sexual behavior; Section III outlines the empirical strategy; Section IV summarizes the data; Section V details the results; and Section VI concludes.

\section{Background}

\section{A. Prevalence of Methamphetamine Use}

Methamphetamine is a stimulant that affects the brain and central nervous system. It is easily manufactured from ephedrine or pseudoephedrine, a common decongestant used in cold medicines such as Sudafed, and a few other chemicals. While the majority of methamphetamine in the U.S. is manufactured in large operations, small methamphetamine manufactures, known as "meth labs," have become common in recent years ( manufacture makes methamphetamine an especially hard drug to combat. 
In 1997, 2.5 percent of U.S. residents age 12 and over had ever used methamphetamine, and methamphetamine use was concentrated among men, with 3.3 percent of men and 1.6 percent of women over age 12 ever using methamphetamine, and concentrated in the Western U.S., where 4.5 percent of residents age 12 and over had ever used methamphetamine. In 2002, just over five percent of U.S. residents age 12 and over had ever used methamphetamine (SAMHSA 2004) and 0.7 percent had used methamphetamine in the past year. Currently, methamphetamine use is concentrated among those of ages 18 to 25 (SAMHSA 2004) and use is split almost equally between men and women (Hunt, Kuck and Truitt 2006).

\section{B. Effects of Methamphetamine Use}

When methamphetamine enters the body it triggers the release of large amounts of dopamine and other neurotransmitters. Brain cells and nervous system cells communicate through neurotransmitters, and the increase in these neurotransmitters produces sensations of self-confidence, energy, alertness, pleasure, and sexual arousal. The high from methamphetamine is very long compared to other substances, lasting from 8 to 24 hours. In comparison, the high from cocaine lasts from 30 minutes to one hour. Methamphetamine is highly addictive, and the trajectory from initial use to steady use and addiction is steep, even when compared to cocaine and heroin (Gonzalez Castro et al. 2000; Hser et al. 2008).

Given its addictive properties and intense, long-lasting highs, methamphetamine use can disrupt many aspects of individuals' lives. Long-term methamphetamine use is neurotoxic, reducing the ability of neurons to release dopamine, possibly leading to depression and suicidal thoughts (CDC 2007; Gonzales, Mooney and Rawson 2010). In addition to mental disorders, methamphetamine use can also lead to tooth decay (commonly referred to as "meth mouth"), 
weight loss, skin lesions and stroke and heart attack (CDC 2007; Gonzales, Mooney and Rawson 2010). In 2005, approximately 10 percent of emergency room admissions in the U.S. contained a mention of methamphetamine use (McBride et al. 2008). Methamphetamine use is also associated with a host of social problems. It has been connected to upwards of 90 percent of the domestic dispute cases in the United States (Gonzales, Mooney and Rawson 2010), and increased child abuse and foster care admissions (Gonzales, Mooney and Rawson 2010; Cunningham and Finlay 2011).

\section{Correlation between Methamphetamine Use and Risky Sexual Behavior}

Many studies also find associations between methamphetamine use and risky sexual

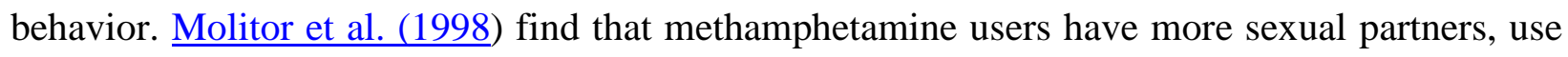
condoms less often, visit prostitutes more frequently, and have sex with a known injection-drug user more often than people who do not use methamphetamine. Zule et al. (2007) find that in heterosexuals, methamphetamine use by both partners is associated with a wide range of highrisk behaviors, including vaginal and anal sex without a condom and sex with a new partner. Although the associations between methamphetamine use and risky sexual behavior are stronger for men, the relationships hold for both men and women. Rawson et al. (2002) find that 74 percent of male methamphetamine users and 67 percent of female methamphetamine users state that "sexual pleasure is enhanced by the use of [methamphetamine]." Furthermore, 53 and 56 percent of male and female methamphetmaine users, respectively, state that they are more likely to practice risky sex while on methamphetamine (Rawson et al. 2002). Compared to nonmethamphetamine users, heterosexual women using methamphetamine are 6.7 times more likely to exchange money or drugs for sex; men who have sex with men (MSM) and who are 
methamphetamine users are 3.4 times more likely to exchange money or drugs for sex; and heterosexual male methamphetamine users are 2.4 times more likely do so (Molitor et al. 1998).

The correlation between methamphetamine use and risky sexual behavior has caused public health officials to suggest methamphetamine control as a means of reducing STIs since the 1990s ( $\underline{\text { Handsfield and Schwebke 1990; }}$ Molitor et al. 1998; Molitor et al. 1999; Halkitis, Parsons and Stirratt 2001; Corsi and Booth 2008). Molitor et al. (1998) state, "With the realization that methamphetamine use has been related to unsafe injection practices, the importance of including methamphetamine prevalence in epidemiologic profiles and prevention strategies becomes apparent.” Their sentiments have been echoed by public health officials. The CDC states that "HIV and STD prevention and treatment programs could be enhanced to include assessment for methamphetamine use, with referrals to methamphetamine treatment, primary testing, and sexual health promotion" (DC 2007). ${ }^{2}$

Much of the research examining methamphetamine use and STIs focuses on MSM. The prevalence of methamphetamine use is particularly high among MSM. One study found that 20 percent of MSM aged 15 to 22 in seven urban areas used methamphetamine during the past six months, and almost six percent used methamphetamine at least once a week (Thiede et al. 2003). The same study found that 32 percent and 28 percent of MSM of ages 15 to 22 in Los Angeles and San Francisco, respectively, used methamphetamine in the past six months and 12 percent and nine percent, respectively, used methamphetamine at least once a week (Thiede et al. 2003). Studies also consistently find a positive association between methamphetamine use and risky sexual behavior among MSM (Molitor et al. 1998; Koblin et al. 2003b; Brewer, Golden and Handsfield 2006; Mansergh et al. 2006; Shoptaw and Reback 2007; Taylor et al. 2007).

\footnotetext{
${ }^{2}$ Elifson, Klein and Sterk (2006) point out that much of the research connecting drug use to risky sexual behavior examines established drug users. They find that risky sexual behavior is not related to methamphetamine use among a sample of new drug users.
} 
Moreover, studies find positive relationships between methamphetamine use and HIV transmission (Molitor et al. 1998; Brewer, Golden and Handsfield 2006; Shoptaw and Reback 2007) and between methamphetamine use and syphilis transmission (CDC 2001; Wong et al. 2005; Shoptaw and Reback 2007).

\section{Potential Causal Mechanisms}

A number of possible causal mechanisms could underlie the positive relationship between methamphetamine use and risky sexual behavior and STIs. First, some effects of methamphetamine may make it a complement to risky sexual behaviors. Methamphetamine creates sensations of euphoria, pleasure and sexual arousal while it lowers inhibitions and clouds judgment. As noted above, methamphetamine users state that they participate in risky sexual behavior more often when using methamphetamine. Second, other effects of methamphetamine may increase the likelihood of STI transmission. Methamphetamine's effects on judgment may decrease condom use. While methamphetamine causes sexual arousal, it also impedes the ability to obtain an erection (Halkitis, Parsons and Stirratt 2001). Thus, MSM who take methamphetamine may be more likely to engage in receptive anal sex, which is more likely to result in STI transmission ( addicts may resort to exchanging sex for money to support their drug habit. ${ }^{3}$

However, the positive correlation observed between methamphetamine use and risky sexual behaviors and STI transmissions may be due to a third factor, such as a preference for risky behavior. Thus, the positive correlations outlined above are not necessarily causal. Previous economic studies find that correlations observed between substance use and risky

\footnotetext{
${ }^{3}$ Methamphetamine and risky sexual behavior may also be substitutes. People with a preference for risky behavior may turn to risky sexual behavior if the high from methamphetamine is not available.
} 
sexual behavior may not be causal. For example, Grossman, Kaestner and Markowitz (2004) and Grossman and Markowitz (2005) study the link between alcohol and marijuana use and teen sexual behavior. Grossman, Kaestner and Markowitz (2004) use the National Longitudinal Survey of Youth 1997 cohort and explicitly account for potential third factors using a bivariate probit model and individual fixed-effects OLS regressions. Grossman and Markowitz (2005) use data from the Youth Risk Behavioral Study and use alcohol and marijuana prices as instrumental variables to mitigate omitted variable bias. Both papers find very limited support for the proposition that alcohol and marijuana use increases risky sexual behavior, although Grossman and Markowitz (2005) find some support for the proposition that alcohol and marijuana use decreases condom and birth control use.

Other economic studies examine additional negative outcomes associated with methamphetamine by using methamphetamine supply shocks to circumvent possible omitted variable bias. Dobkin and Nicosia (2009) use the May 1995 shock used in this paper to examine the causal effect of methamphetamine use on crime. They find little evidence that the decrease in methamphetamine use affected either violent crime or property crime. Cunningham and Finlay (2011) use the May 1995 and October 1997 shocks used in this paper to identify a causal relationship between methamphetamine use and foster care and parental neglect. They find that methamphetamine use is positively related to foster care caseloads.

\section{E. Exogenous Variation in Methamphetamine Use}

In our main analysis, we use a supply shock to the market for methamphetamine in mid1995 to estimate the causal impact of methamphetamine use on risky sexual behavior. In May 1995, the DEA raided the Pennsylvania-based Clifton Pharmaceuticals company, seizing about 
25 metric tons of pseudoephedrine powder (Subcommittee on Crime of the Committee of the Judiciary 1995). The seized products filled five 53-foot semi-trailers and were enough to manufacture about 15.6 metric tons of methamphetamine under an average meth lab conversion rate of 62.5 percent (Dobkin and Nicosia 2009). At current prices, 15 tons of methamphetamine would sell for roughly $\$ 4$ billion. ${ }^{4}$ In addition, on May 31, 1995, the DEA executed a search warrant at the Atlanta offices of the Florida-based mail-order company, X-Pressive Looks, Inc. (XLI), seizing about 37.5 million pseudoephedrine tablets, and shut down the company's distribution in August 1995 (U.S. v. Prather 2000). Between April 1994 and August 1995, XLI distributed more than 830 million pseudoephedrine tablets. This reduces to about 20.8 metric tons of pseudoephedrine, enough to manufacture about 13 metric tons of methamphetamine. In comparison, total methamphetamine consumption in the entire United States in 1994 was 34.1 metric tons (Office of National Drug Policy Control 2001, Table 8). Dobkin and Nicosia (2009) characterize the two interventions in May 1995 as the largest supply shock in U.S. drug enforcement history. Previous research by Cunningham and Liu (2003) and Dobkin and Nicosia (2009) finds that between August 1995 and September 1996, this shock led to a temporary increase in price, decrease in purity, and decrease in amphetamine-related hospitalizations and treatment center admissions in California. Cunningham and Finlay (2011) find that the 1995 supply shock led to a national increase in methamphetamine price and decrease in purity.

In additional analysis, we use a second, later methamphetamine supply shock stemming from the Methamphetamine Control Act (MCA). The MCA, signed into law by President Clinton in October 1996, included many measures to control methamphetamine use. The law increased the jurisdiction of U.S. law for crimes related to the manufacture of methamphetamine

\footnotetext{
${ }^{4}$ See Damien Cave, “Mexico Seizes Record Amount of Methamphetamine," New York Times, available at http://www.nytimes.com/2012/02/10/world/americas/mexico-seizes-15-tons-of-methamphetamine.html (accessed March, 2013).
} 
outside the U.S. for importation into the U.S. and increased penalties for methamphetaminerelated crimes committed within U.S. borders. Additionally, effective October 3, 1997, the MCA limited to 24 grams the unregulated single transaction quantities of pseudoephedrine, phenylpropanolamine, or combination ephedrine products. The MCA also required manufacturers and distributors of ephedrine and pseudoephedrine to register with the Federal Government as manufacturers or distributors of controlled substances (U.S. Drug Enforcement Agency 1997). Previous research by Cunningham and Liu (2003) finds that this supply shock reduced amphetamine-related hospitalizations by 53 percent, and Cunningham and Finlay (2011) find that the 1997 supply shock caused a national deviation in methamphetamine prices beginning in April 1998 and lasting until March 1999.

\section{Empirical Strategy}

Our empirical strategy aims to identify the causal relationship between methamphetamine use and risky sexual behavior. We seek to estimate the following equation for county $i$ in year $t$ and month $m$ :

$$
\log \left(S_{i t m}\right)=\alpha_{0}+\alpha_{H} \log \left(A_{i t m}\right)+\alpha_{D} \log \left(D_{i t m}\right)+\alpha_{X} X_{i t m}+\eta_{i}+\rho_{t}+\sigma_{m}+\varepsilon_{i t m}
$$

where $S_{i t m}$ is a measure of risky sexual behavior, the number of syphilis diagnoses per 100,000 people; $A_{i t m}$ is a measure of methamphetamine use, amphetamine-related hospital admissions per 100,000; $D_{\text {itm }}$ represents hospital admissions related to alcohol and other controlled substances per 100,000; $X_{i t m}$ represents county demographic characteristics; and $\eta_{i}, \rho_{t}$ and $\sigma_{m}$ represent county, month and year fixed effects.

As both methamphetamine use and risky sexual behavior could be caused by an unobservable third factor, estimating the above equation will possibly lead to biased coefficients. 
To circumvent this problem, we use a large exogenous supply shock to the market for methamphetamine. As discussed above, the DEA's closure of two pharmaceutical firms in May 1995 caused a temporary increase in methamphetamine prices and decrease in amphetaminerelated hospitalizations between August 1995 and September 1996. In addition, restrictions in the MCA that went into effect in October 1997 caused a national deviation in methamphetamine prices between April 1998 and March 1999. We use each of these shock periods as an instrumental variable in a two-stage least-squares estimation,

$$
\log \left(S_{i t m}\right)=\alpha_{0}+\alpha_{H} \log \left(\hat{A}_{i t m}\right)+\alpha_{D} \log \left(D_{i t m}\right)+\alpha_{X} X_{i t m}+\eta_{i}+\rho_{t}+\sigma_{m}+\varepsilon_{i t m},
$$

where $\hat{A}_{\mathrm{itm}}$ is estimated by the first-stage equation,

$$
\log \left(A_{i t m}\right)=\beta_{0}+\beta_{I} I_{i t m}+\beta_{D} \log \left(D_{i t m}\right)+\beta_{X} X_{i t m}+\eta_{i}+\rho_{t}+\sigma_{m}+\varepsilon_{i t m} .
$$

In Equation (3), $I_{i t m}$ is an indicator for the time period of the supply shock. In our main analysis, we estimate equations (2) and (3) over the period from 1994 to 1997, using August 1995 to September 1996 as the period of the supply shock. In additional analysis, we estimate these equations over the period from 1997 to 2000, using April 1998 to March 1999 as the period of the supply shock.

In all regressions, we control for the use of other substances that may affect risky sexual behaviors (in the $D$ matrix). We include controls for alcohol use, marijuana use, cocaine use, and heroin use. We also include county-level variables that may determine syphilis transmissions (in the $X$ matrix). We include county population density, as well as the percent of each county's population that is male, black, Hispanic, under age 18, and between the ages of 18 and 39. We cluster the standard errors at the county level (Bertrand, Duflo and Mullainathan 2004). 


\section{Data}

We proxy for risky sexual behavior with monthly, early-stage syphilis diagnoses at the county level from the California Department of Public Health (CDPH). The counts are based on syphilis diagnoses sent from medical providers and laboratories to local health departments, which forward them to the CDPH. These data represent the population of early-stage syphilis diagnoses in California.

Syphilis is a sexually transmitted disease that is caused by the bacteria Treponema pallidum. Transmission occurs by direct contact with a syphilis sore. In 2010, 45,834 people in the U.S. were diagnosed with syphilis at any stage (CDC 2011b). Caught in its early stages, syphilis is easily treated with an injection of antibiotics. Syphilis infections generally go through three stages. In the primary stage, one or a few sores develop around the area where syphilis entered the body. The sores develop in as few as 10 days, although usually around 21 days, and last for 3 to 6 weeks. If the disease is not treated, the infection moves to a secondary stage. In the secondary stage, the original sores usually heal, but rashes develop on different parts of the body. Without treatment, the rashes usually heal and the disease moves into its latent and late stages. In the latent and late stages, syphilis remains dormant, often for many years, and then may reemerge, often attacking the brain or other vital organs.

Since syphilis symptoms develop in as few as 10 days, syphilis provides a timely indicator of risky sexual behavior. In comparison, HIV symptoms may not manifest for many years (Bacchetti and Moss 1989). Examining syphilis is important not only as an indicator of risky sexual behavior. The prevalence of HIV among syphilis patients is very high. One study of syphilis patients in several large cities in the U.S. found that 18 percent of the patients were also 
infected with HIV (Rolfs et al. 1997). Medical evidence suggests that syphilis sores interfere with the body's mechanisms against HIV transmission (Spinola et al. 1996; Levine et al. 1998). ${ }^{5}$

We use monthly amphetamine-related hospital admissions at the county level as our proxy for methamphetamine consumption. These data come from the census of hospitalizations output by the California Office of Statewide Health Planning and Development (OSHPD). The hospitalization census records the ICD codes for the principal diagnosis and additional diagnoses, and we isolate hospitalizations involving amphetamines. Consistent with Dobkin and Nicosia (2009), we choose ICD codes 304.4X (amphetamine and other psychostimulant dependence), 305.7X (amphetamine or related acting sympathomimetic abuse), 969.7 (psychostimulant poisoning), and E854.2 (accidental psychostimulant poisoning). We also employ the OSHPD data to measure the use of other substances that may affect risky sexual behavior. We include alcohol hospitalizations (ICD codes 291.X, 303.X, 305.X), cannabis hospitalizations (304.3X and 305.2X), heroin hospitalizations (304.0X, 304.7X, and 305.5X) and cocaine hospitalizations (304.2X, and 305.6X).

Table 1 provides summary statistics for the two sample periods: 1994 to 1997 and 1997 to 2000 . The total number of observations in each sample is 2,784 , corresponding to 58 counties measured over 48 months. The average rate of primary syphilis diagnoses in a county in each month is about 0.18 per 100,000 people in the first sample, falling to 0.10 per 100,000 people in the later time period. In both periods, the average syphilis rate is higher among men ( 0.20 and 0.12) than among women (0.16 and 0.08). The monthly average rate of amphetamine-related

\footnotetext{
${ }^{5}$ Another possible proxy for risky sexual behavior is gonorrhea diagnoses. Gonorrhea is the most prevalent STI in the United States, with more than 700,000 new infections every year (CDC 2011a). Like syphilis, gonorrhea symptoms develop quickly after transmission, within 2 to 5 days for women and one month for men. Unfortunately, gonorrhea diagnoses are only available annually for our time period.
} 
hospitalizations is about 5.8 per 100,000 in each county in the first period and 4.8 per 100,000 in the second period, and the rate is only slightly higher among men than among women.

\section{Results}

\section{A. Graphical Results}

We preview our regression results by showing some suggestive graphical evidence. Figure 1 shows the aggregate trends of amphetamine-related hospitalizations and diagnoses of primary syphilis for California from 1994 to 2000. The red line marked with +'s tracks amphetaminerelated hospital admissions, and the green line marked with x's tracks primary syphilis diagnoses. The dashed, vertical, black lines mark the August 1995 to September 1996 methamphetamine supply shock, and the dashed, vertical, blue lines mark April 1998 to March 1999, the period of the second supply shock. During the four months after the 1995 supply shock, amphetamine-related hospital admissions for both men and women dropped to less than 50 percent of their July 1995 value. By October 1996, the end of the supply shock period, amphetamine-related hospitalizations rebounded to roughly 74 percent of their pre-shock value for men and women combined and 70 percent of their pre-shock value for women. However, during the methamphetamine supply shock period, syphilis diagnoses were relatively unchanged, continuing a slow trend downward that began in the early 1990s. Although the decline in amphetamine-related hospitalizations was not as abrupt for the second supply shock, hospitalizations fell by roughly 35 percent throughout the time period of the second shock. Unlike in the 1995 shock, amphetamine-related hospitalizations did not fully recover to their pre-

shock levels. Notably, syphilis diagnoses continued their long-term downward trend before, during, and after the second shock period. 


\section{B. First Stage Results using 1995 Supply Shock}

Before showing regressions that estimate the relationship between methamphetamine use and syphilis, we show evidence of the effects of the 1995 supply shock on the consumption of methamphetamine. Table 2 displays regressions of the effect of the supply shock on amphetamine-related hospitalizations, our proxy for methamphetamine consumption. We estimate the models for the period from 1994 to 1997, examining the period from 1997 to 2000 in later analysis. We stop our analysis at the end of 2000 to avoid contaminating our results with the effects of subsequent methamphetamine precursor regulations. ${ }^{6}$

The dependent variable in all models is the log of the amphetamine-related hospital admissions rate. We estimate models for the total rate and separately for each gender-specific rate. The independent variable of interest is an indicator variable that covers the period of the methamphetamine supply shock, August 1995 to September 1996. The 1995 supply shock reduced amphetamine-related hospitalizations by roughly 30 percent. For men, the decrease was 32 percent, and for women, the decrease was 27 percent. These results are consistent with those of Dobkin and Nicosia (2009) who find a decrease of between 30 and 40 percent and Cunningham and Liu (2003) who find a decrease of between 35 and 53 percent.

To test the dynamic effects of the supply shock, we follow the methodology of Wolfers (2006) and separate the August 1995 to September 1996 period into four sub-periods: one to two months after the shock, three to six months after the shock, seven to nine months after the shock and 10 to 13 months after the shock. We also include indicators for the two months prior to the shock window, the three months after the shock window and the period more than three months after the shock window.

\footnotetext{
${ }^{6}$ These include the Methamphetamine Antiproliferation Act of 2000 and the Combat Methamphetamine Epidemic Act of 2005.
} 
Table 3 shows the results of these regressions. The two months before and three months after the shock do not significantly affect amphetamine-related hospitalization rates. All subperiods of the August 1995 to September 1996 period are associated with statistically-significant decreased amphetamine-related hospitalization rates for combined genders and men and women separately. The coefficients indicate that the effect of the shock was generally greatest during the first six months, before dropping by a third towards the end of the supply-shock period. In the first two months, the shock lowered the amphetamine-related hospital admissions rate by 25 percent. In the following three months, the shock reduced the admissions rate by 41 percent, and in the last three months, it decreased the admissions rate by 22 percent. The dynamic effects of the shock are similar when examined separately for each gender, although the effects are longer lasting for women.

The coefficients for alcohol, cannabis, and cocaine admissions are consistently positive and significant in Tables 2 and 3, providing evidence of a complementary relationship between methamphetamine and other substances. A larger portion of males in a county increases amphetamine-related admissions, while the portion of African Americans in a county decreases amphetamine-related admissions.

\section{Two-Stage Least-Squares Results using 1995 Supply Shock}

Next, we show the effects of methamphetamine use on syphilis. Table 4 shows results from two-stage least-squares regressions where the dependent variable is the logged rate of primary syphilis diagnoses. We run models using total primary syphilis diagnoses and diagnoses for men and women separately. The independent variable of interest in each specification is the logged rate of amphetamine-related hospital admissions, instrumented for by the indicator 
variable for the period of August 1995 to September 1996. In the models examining either male or female syphilis diagnoses, we include the logged rate of amphetamine-related hospital admissions for that gender. All models also include the same controls as in Tables 2 and 3, and standard errors clustered at the county level are reported in parentheses. Following the STI literature (e.g. Chesson, Harrison and Kassler 2000; Dee 2008; Francis and Mialon 2010), we also run specifications including a lagged dependent variable to account for the communicable nature of syphilis. ${ }^{7}$

Amphetamine-related hospitalizations have no statistically significant effect on total syphilis rates or male syphilis rates. However, a reduction of amphetamine-related hospitalizations is associated with a statistically significant increase in syphilis among women. The estimated elasticities of syphilis among women with respect to amphetamine-related hospitalization are -0.50 to -0.56 . Few of the other explanatory variables affect syphilis transmission, including the prevalence of other substance use. The number of individuals between ages 18 and 39 increases syphilis transmission, corroborating national estimates that syphilis is most prevalent among individuals age 20 to 24 (CDC 2011b).

For all models, we report the Partial R-Squared and Kleibergen-Paap Wald F Statistic, measures of the strength of the correlation between our excluded instrumental variable and our endogenous variable. Additionally, we report Hausman Test P-Values to check for the endogeneity of the excluded variable. In all models in Table 4, the Kleibergen-Paap Wald F Statistics are very high, rejecting the null hypothesis of weak identification at the one percent level. The Hausman Tests suggest that methamphetamine use may be endogenous in the

\footnotetext{
${ }^{7}$ In panel data models, a lagged dependent variable may bias coefficients, as the lagged dependent variable is correlated with the mean of the dependent variable. In long panels this bias diminishes because the lagged dependent variable only comprises $1 / \mathrm{N}$ of the mean. Since our panel is 48 periods long, we decided to include the lagged dependent variable rather than estimating an Arellano-Bond type dynamic panel data model.
} 
specifications for women, but also suggest that methamphetamine use may not be endogenous in the male and combined genders specifications. We revisit this issue in our robustness checks section.

\section{Fixed Effects Poisson Estimation using 1995 Supply Shock}

One potential issue with using a logged rate of syphilis as our dependent variable is that there are county-month observations with no syphilis diagnoses. To check whether this impacted our results, we also show results from a fixed effects Poisson model incorporating endogenous variables using a two-step procedure described in Wooldridge (2002). In the first stage, we regress the rate of methamphetamine admissions on the supply shock and other independent variables. We use the residuals from the first stage as an additional regressor in the second stage, estimated by a Poisson regression with robust standard errors clustered at the county level (Bertrand, Duflo and Mullainathan 2004). As in other models, we include county, year, and month fixed effects. The results from these regressions are shown in Table $5 .{ }^{8}$ As with Table 4 , methamphetamine use is not statistically significantly related with syphilis rates, although the elasticities for women, at -0.19 to -.20 , are not statistically significant.

\section{Methamphetamine Control Act of 1996}

We now test the robustness of our results to a second, later methamphetamine supply shock stemming from the Methamphetamine Control Act of 1996 (MCA). As noted above, the law required manufacturers and distributors of ephedrine and pseudoephedrine to register with

\footnotetext{
${ }^{8}$ The number of observations is different from that in Table 4 because the fixed effects estimation necessitates removing any counties with no variation in the dependent variable. There are four, nine, and eight counties with no total, male and female syphilis diagnoses in our sample period, respectively. We also re-estimated Table 4 using the same sample as the Poisson estimation and found virtually identical results.
} 
the Federal Government beginning in October 1997 and restricted the maximum quantity of over-the-counter pseudoephedrine sales (U.S. Drug Enforcement Agency 1997). We estimate regression models parallel to those in Tables 2 through 5 over the period from 1997 to 2000. Following Cunningham and Finlay (2011), we use the period from April 1998 to March 1999 as the period of the second shock. Tables 6 through 9 show results from these regressions, which are generally consistent with Tables 2 through 5 .

Tables 6 and 7 show the MCA's effects on amphetamine-related hospitalizations. In Table 6, the MCA shock period reduced amphetamine-related hospitalizations by roughly 15 percent. In Table 7, we estimate the dynamic effects of this second supply shock. As in Table 3, we separate the April 1998 to March 1999 period into four sub-periods: one to two months after the shock, three to six months after the shock, seven to nine months after the shock and 10 to 11 months after the shock. We also include indicators for the two months prior to the shock window, the three months after the shock window and the period more than three months after the shock window. Dynamically examining the shock, the two months just before the shock period are not associated with reduced amphetamine-related hospitalizations, while the first two periods of the shock are associated with a 16 percent decrease in amphetamine-related hospitalizations. These results support the April 1998 start date of the shock estimated by Cunningham and Finlay (2011). The largest effects of the MCA occurred between October 1998 and January 1999, where amphetamine-related hospitalizations were 31 percent lower than before the supply shock. The effects of the MCA supply shock were longer lasting than the effects of the 1995 supply shock. The coefficients for the three months after the supply shock period and time period more than three months after the shock period are both negative and statistically significant. These effects are especially evident for women, where the time periods 
after the end of the shock show larger decreases in amphetamine-related admissions than during the shock period. We revisit this issue in our robustness checks in the next section.

As in Tables 2 and 3, methamphetamine and other substances show a complementary relationship, although the relationship is stronger during the period of the second shock than during that of the first shock. The elasticity of amphetamine-related hospital admissions with respect to hospital admissions related to alcohol, cannabis, heroin, and cocaine are $0.24,0.25$, 0.07, and 0.11, respectively. While alcohol and methamphetamine are stronger compliments for men, heroin and methamphetamine are stronger compliments for women.

In Tables 8 and 9, we estimate models parallel to those in Tables 4 and 5, using the time period of the second supply shock as an instrumental variable to estimate the causal relationship between methamphetamine consumption and risky sexual behavior. In all models in Table 8 , the Kleibergen-Paap Wald F Statistics are very high, rejecting the null hypothesis of weak identification at the one percent level. Methamphetamine consumption is not statistically associated with syphilis diagnoses in any of the specifications. Additionally, alcohol use is associated with syphilis diagnoses in the specification for combined genders, with the association being driven by men. In Table 9, we estimate models parallel to those in Table 5, using a fixed effects Poisson regression with a control function. As in Table 5, there is little evidence that methamphetamine consumption and syphilis are statistically related. As in Table 8, alcohol use is positively associated with syphilis diagnoses for men, but in the Poisson specifications, the coefficients for alcohol use in the female regressions are negative and statistically significant.

There are several reasons why we consider the analysis of the 1995 supply shock period to be more convincing than the analysis of the 1998 shock period. First, the second shock period is a much weaker instrument. The Partial R-Squared statistics are about four times smaller using 
the MCA shock, and the Kleibergen-Paap Wald F Statistics are generally half as large. Second, as is evident from Figure 1, there are fewer primary syphilis diagnoses in the later time period. Third, as detailed below, the introduction of highly active antiretroviral therapy increased overall HIV transmission rates after 1998 and thus may separately influence risky sexual behavior. Lastly, as the MCA was passed to combat rising methamphetamine rates, it raises more concerns about policy endogeneity than the 1995 supply shock.

\section{E. Robustness Checks}

We estimated a number of other specifications to test the robustness of our results. The detailed findings of these robustness checks are available in the Appendix. First, the Hausman PValues in Tables 4 and 8 suggest that methamphetamine use may not be an endogenous variable in several of the models. Thus, we also ran OLS regressions and Fixed-Effects Poisson regressions without a control function, specifications otherwise parallel to the models in Tables 4, 5, 8 and 9, to check the robustness of the instrumental variables framework. The results are similar to those in the original tables. The greatest change in the OLS and Fixed-Effects Poisson models is that methamphetamine use is not related to syphilis even for women. However, in Tables 4 and 5, the Hausman Tests suggest that methamphetamine use may be endogenous for women, and thus OLS models may not be appropriate.

Second, as lagged male syphilis rates or male substance use may also relate to female syphilis, we ran specifications testing the robustness of the negative and statistically significant effect of methamphetamine use on female syphilis rates. First, we estimated models of female syphilis rates, replacing the measures of female methamphetamine and substance use with male methamphetamine and substance use. Second, we also included the lagged prevalence of male 
syphilis instead of the lagged prevalence of female syphilis. For each specification, we estimated IV, Fixed Effects Poisson control function, and OLS models using the 1995 and 1998 supply shock periods. The results of these alternative specifications are similar to the original results. The effect of methamphetamine use on female syphilis rates remains negative and statistically significant in the IV specification using the 1995 supply shock but insignificant in the other specifications.

Third, the dynamic analysis of the 1998 supply shock period suggests that the supply shock period may extend after March 1999. Thus, we re-estimated Tables 6, 8, and 9 using the time period from April 1998 until December 2000 as the period of the second supply shock. In the first stage regression, the extended shock period is associated with a larger 28 percent decline in amphetamine-related hospital admissions and the remaining coefficients are fairly consistent. In the second stage instrumental variables specifications, male methamphetamine consumption is not statistically related to male syphilis diagnoses while the coefficient for female methamphetamine consumption is negative and statistically significant. However, in the fixed effects Poisson specifications using a control function, all coefficients on methamphetamine admissions are small and not statistically significant.

Lastly, we combined the two supply shocks to analyze the period from 1994 to 2000. More specifically, we created an indicator variable equal to one during either one of the supply shock periods and equal to zero otherwise and reestimated our results over the extended period of 1994 to 2000. Our results are largely unchanged. The two supply shocks caused a decrease in amphetamine-related hospital admissions of just over 21 percent, and methamphetamine and other controlled substances remain economic complements. In the IV specifications, the supply shocks did not affect syphilis diagnoses for men, but increased syphilis diagnoses for women. 
However, neither male nor female syphilis diagnoses were statistically related to amphetaminerelated hospitalizations in the fixed effects Poisson specifications.

\section{F. Other Potential Issues}

One concern is that other behavioral factors, such as the introduction of antiretroviral drugs, changed the costs of risky sexual behaviors concurrently with the amphetamine shock. Previous economic research finds that the introduction of highly active antiretroviral therapy (HAART) increased the overall HIV transmission rate in the late 1990s (Lakdawalla, Sood and Goldman 2006). HAART became the standard method to treat HIV infections by 1997, and some HIV patients received early access to HAART by December 1995. However, Lakdawalla, Sood and Goldman show that the change in HIV infection rates did not begin until 1998, which is after the end date of our main analysis using the 1995 supply shock.

Second, it is possible that methamphetamine users increased usage of other drugs in response to the amphetamine supply shock. Dobkin and Nicosia (2009) find little evidence that the shock induced users to switch to other illicit drugs. Nevertheless, we control for the prevalence of other drug use through the hospitalization rates of alcohol, marijuana, heroin, and cocaine. We find that other drug use is not correlated with syphilis transmissions, suggesting that substitution of other drugs may not be an issue.

It is also possible that the methamphetamine shocks caused a change in methamphetamine purity, as the drug could be "cut" with other substances. If the drug is cut with substances that are more harmful to users, our rate of amphetamine-related hospitalizations may overstate the decrease in methamphetamine consumption. Alternatively, if the drug is cut with substances that are less harmful to users, our rate of amphetamine-related hospitalizations 
may understate the decreases in methamphetamine consumption. Methamphetamine is usually cut with substances that are available as dietary supplements over the counter. For example, methamphetamine is commonly cut with methylsulfonylmethane, a dietary supplement sold at, among other places, health food stores and high-end grocery stores. ${ }^{9}$ There is also evidence that, after the amphetamine supply shock, methamphetamine was increasingly cut with phenylpropanolamine, which is also available as a dietary supplement. ${ }^{10}$

Relatedly, it may be that only a small number of methamphetamine users are ever hospitalized for methamphetamine consumption. If amphetamine-related hospitalizations are concentrated among one type of methamphetamine user, hospitalizations may overstate or understate the effects of the amphetamine shock. However, Dobkin and Nicosia (2009) find that amphetamine-related admissions for common diagnosis-related groups (which include psychoses, alcohol and drug detoxification and treatment, and pregnancy and delivery) follow the same trend. This suggests that overall hospital admissions are a reasonable proxy for methamphetamine consumption. Furthermore, the use of methamphetamine may be even more disruptive to daily life and result in hospitalization even more rapidly and frequently than use of most other illicit drugs. When smoked, cocaine brings a high that lasts between 20 and 30 minutes, while methamphetamine brings a high that lasts between 8 and 24 hours (Gawin and Ellinwood 1988; National Institute on Drug Abuse 1998). In addition, Gonzalez Castro et al. (2000) find that the period from first use to regular use is even shorter for methamphetamine users than for cocaine users.

\footnotetext{
${ }^{9}$ See “Information Bulletin: Crystal Methamphetamine,” from the National Drug Intelligence Center, available at http://www.justice.gov/archive/ndic/pubs1/1837/1837t.htm (accessed March, 2013).

${ }^{10}$ See The Clandestine Laboratory Investigating Chemists Association, available at http://www.erowid.org/archive/rhodium/chemistry/clic.html (accessed March, 2013).
} 
The number of early syphilis cases may also be an imperfect proxy for risky sex. While risky sex is certainly associated with syphilis incidence rates, other factors such as increased syphilis screening at "high risk" venues, provider education regarding symptom recognition, and/or reporting requirements could potentially impact observed syphilis trends in specific areas at specific times, and obscure the true relationships of risky sex and syphilis rates. However, these factors are unlikely to have varied abruptly within the span of a few months following the May 1995 methamphetamine supply shock and to have varied systematically by county.

A related concern is that syphilis diagnoses are too rare in the mid to late 1990s. As shown in Figure 1 and Table 1, syphilis rates fell in California throughout the 1990s. Although more recent years may contain more variation in syphilis rates, the 1995 supply shock (and to a lesser extent, the MCA shock) provides a more clean and exogenous identification strategy than would policy variation present in more recent years. It is also possible that while there is no relationship between methamphetamine and risky sex during the mid to late 1990s, a causal relationship developed more recently. Nonetheless, medical and public health literature studying methamphetamine use and risky sexual behavior consistently found a correlation between the two in the mid-to-late 1990s (Molitor et al. 1998; Molitor et al. 1999; Halkitis, Parsons and

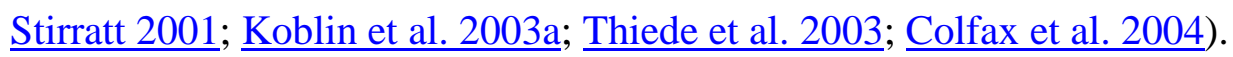

\section{Conclusion}

This paper attempts to estimate the causal relationship between methamphetamine use and risky sexual behavior using county-level monthly data from California. To identify a causal relationship, we focus on a large exogenous shock to the methamphetamine market during the period from August 1995 to September 1996 and a second supply shock during the period of 
April 1998 to March 1999. We measure methamphetamine consumption using amphetaminerelated hospital admissions and risky sexual behavior using syphilis diagnoses. Consistent with previous studies, we find that the supply shocks had large effects on methamphetamine consumption, proxied for by amphetamine-related hospital admissions. However, we find no evidence that the drastic decrease in methamphetamine consumption affected syphilis diagnoses.

Oddly, we find some evidence that the decreased methamphetamine consumption associated with the August 1995 to September 1996 shock period increased female syphilis transmission, although this relationship is not present in all specifications. One possible explanation is that the drastically higher methamphetamine prices following the shock led some women to trade sex for drugs. Medical and epidemiologic research has long associated drug use,

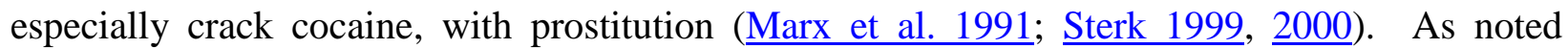
earlier, previous medical research estimates that heterosexual women who use methamphetamine are 6.7 times more likely to have received money or drugs for sex than heterosexual women who do not use methamphetamine (Molitor et al. 1998). Semple et al. (2011) report that 31 percent of females enrolled in a sexual risk reduction intervention in San Diego traded sex for methamphetamine in the past two months, while Cheng et al. (2009) report that 34 percent of female methamphetamine users in San Diego have ever traded methamphetamine for sex. Other studies find that between 15 and 22 percent of women methamphetamine users recently exchanged sex for money (Semple, Grant and Patterson 2004). Methamphetamine use is also high among female sex workers (Patterson et al. 2006; Rusch et al. 2010; Kang et al. 2011).

Our results suggest that policies to reduce methamphetamine use may not reduce the prevalence of syphilis and other STIs. This is troubling, as methamphetamine use is increasingly targeted as a means of decreasing STIs among gay and bisexual men and other high-risk 
populations. Efforts to reduce STIs may be better centered around other policies, such as those that may increase access to health care, increase screening of at-risk populations, better help to find and treat partners of infected persons, and provide information on sexual health.

Future research may explore the relationship between methamphetamine use and risky sexual behavior using more recent policy variation and other measures of STIs. Over the past decade, many states have enacted methamphetamine precursor laws in response to the spread of small toxic lab production of methamphetamine (McBride et al. 2008). However, identifying the effect of methamphetamine use on risky sexual behavior through variation in these more recent laws may be more difficult than identifying the effect through the supply shocks of earlier periods, as we did here. The earlier supply shocks provide a cleaner and more exogenous identification strategy. More recent periods have additional confounding factors, such as the widespread use of antiretroviral drugs. Moreover, the majority of recent state precursor laws were enacted around the same period (2004 to 2006) and alongside federal precursor legislation (specifically, the Combat Methamphetamine Epidemic Act of 2005). In addition, these state laws vary widely along several dimensions, including purchase limits (e.g., pack limits, per transaction limits, and/or time frame limits), sales environment restrictions (e.g., behind the counter, ID required, and/or sales to minors prohibited), and possession restrictions (quantity limits, offense severity, possession with intent to manufacture, etc.). Nonetheless, variation in these state laws provides a promising avenue for further investigation of the link between methamphetamine and the spread of STIs. 


\section{References}

Anderson, D. M. (2010). "Does information matter? The effect of the Meth Project on meth use among youths." Journal of Health Economics 29(5): 732-742.

Bacchetti, P. and A. R. Moss (1989). "Incubation period of AIDS in San Francisco." Nature 338(6212): 251-253.

Bertrand, M., E. Duflo and S. Mullainathan (2004). "How much should we trust differences-indifferences estimates?" Quarterly Journal of Economics 119(1): 249-275.

Brewer, D. D., M. R. Golden and H. H. Handsfield (2006). "Unsafe sexual behavior and correlates of risk in a probability sample of men who have sex with men in the era of highly active antiretroviral therapy." Sexually Transmitted Diseases 33(4): 250-255.

Centers for Disease Control and Prevention (2001). "Outbreak of syphilis among men who have sex with men--Southern California, 2000." Morbidity and Mortality Weekly Report 50(7): 117-120.

Centers for Disease Control and Prevention. (2007). "Methamphetamine use and risk for HIV/AIDS." from http://www.cdc.gov/hiv/resources/factsheets/meth.htm.

Centers for Disease Control and Prevention. (2011a). "Gonorreah - CDC Fact Sheet." from http://www.cdc.gov/std/gonorrhea/gonorrhea-fact-sheet-April-2011.pdf.

Centers for Disease Control and Prevention (2011b). Sexually transmitted disease surveillance 2010. Atlanta, U.S. Department of Health and Human Services.

Cheng, W. S., R. S. Garfein, S. J. Semple, et al. (2009). "Differences in sexual risk behaviors among male and female HIV-seronegative heterosexual methamphetamine users." American Journal of Drug and Alcohol Abuse 35(5): 295-300.

Chesson, H., P. Harrison and W. J. Kassler (2000). "Sex under the influence: The effect of alcohol policy on sexually transmitted disease rates in the United States." Journal of Law and Economics 43(1): 215-238.

Colfax, G., E. Vittinghoff, M. J. Husnik, et al. (2004). "Substance use and sexual risk: a participant- and episode-level analysis among a cohort of men who have sex with men." American Journal of Epidemiology 159(10): 1002-1012.

Corsi, K. F. and R. E. Booth (2008). "HIV sex risk behaviors among heterosexual methamphetamine users: literature review from 2000 to present." Current Drug Abuse Reviews 1(3): 292-296. 
Cunningham, J. K. and L. M. Liu (2003). "Impacts of federal ephedrine and pseudoephedrine regulations on methamphetamine-related hospital admissions." Addiction 98(9): 12291237.

Cunningham, S. and K. Finlay (2011). "Parental substance abuse and foster care: Evidence from two methamphetamine supply shocks." Working Paper.

Dee, T. S. (2008). "Forsaking all others? The effects of same-sex partnership laws on risky sex." Economic Journal 118(530): 1055-1078.

Dobkin, C. and N. Nicosia (2009). "The war on drugs: methamphetamine, public health, and crime." American Economic Review 99(1): 324-349.

Elifson, K. W., H. Klein and C. E. Sterk (2006). "Predictors of sexual risk-taking among new drug users." Journal of Sex Research 43(4): 318-327.

Francis, A. M. and H. M. Mialon (2010). "Tolerance and HIV." Journal of Health Economics 29(2): 250-267.

Gawin, F. H. and E. H. Ellinwood, Jr. (1988). "Cocaine and other stimulants. Actions, abuse, and treatment." New England Journal of Medicine 318(18): 1173-1182.

Gonzales, R., L. Mooney and R. A. Rawson (2010). "The methamphetamine problem in the United States." Annual Review of Public Health 31: 385-398.

Gonzalez Castro, F., E. H. Barrington, M. A. Walton, et al. (2000). "Cocaine and methamphetamine: differential addiction rates." Psychology of Addictive Behaviors 14(4): 390-396.

Grossman, M., R. Kaestner and S. Markowitz (2004). "Get high and get stupid: The effect of alcohol and marijuana use on teen sexual behavior." Review of Economics of the Household 2(4): 413-441.

Grossman, M. and S. Markowitz (2005). "I did what last night?! Adolescent risky sexual behaviors and substance use." Eastern Economic Journal 31(3): 383-405.

Halkitis, P. N., J. T. Parsons and M. J. Stirratt (2001). "A double epidemic: crystal methamphetamine drug use in relation to HIV transmission among gay men." Journal of Homosexuality 41(2): 17-35.

Handsfield, H. H. and J. Schwebke (1990). "Trends in sexually transmitted diseases in homosexually active men in King County, Washington, 1980-1990." Sexually Transmitted Diseases 17(4): 211-215.

Hser, Y. I., D. Huang, M. L. Brecht, et al. (2008). "Contrasting trajectories of heroin, cocaine, and methamphetamine use." Journal of Addictive Diseases 27(3): 13-21. 
Hunt, D., S. Kuck and L. Truitt (2006). Methamphetamine use: lessons learned. Cambridge, MA, National Institute of Justice.

Kang, D., M. Liao, Z. Jiang, et al. (2011). "Commercial sex venues, syphilis and methamphetamine use among female sex workers." AIDS Care 23 Suppl 1: 26-36.

Koblin, B. A., M. A. Chesney, M. J. Husnik, et al. (2003a). "High-risk behaviors among men who have sex with men in 6 US cities: baseline data from the EXPLORE Study." American Journal of Public Health 93(6): 926-932.

Koblin, B. A., M. A. Chesney, M. J. Husnik, et al. (2003b). "High-risk behaviors among men who have sex with men in 6 US cities: baseline data from the EXPLORE Study." American Journal of Public Health 93(6): 926-932.

Lakdawalla, D., N. Sood and D. Goldman (2006). "HIV breakthroughs and risky sexual behavior." Quarterly Journal of Economics 121(3): 1063-1102.

Levine, W. C., V. Pope, A. Bhoomkar, et al. (1998). "Increase in endocervical CD4 lymphocytes among women with nonulcerative sexually transmitted diseases." Journal of Infectious Diseases 177(1): 167-174.

Mansergh, G., R. L. Shouse, G. Marks, et al. (2006). "Methamphetamine and sildenafil (Viagra) use are linked to unprotected receptive and insertive anal sex, respectively, in a sample of men who have sex with men." Sexually Transmitted Infections 82(2): 131-134.

Marx, R., S. O. Aral, R. T. Rolfs, et al. (1991). "Crack, sex, and STD." Sexually Transmitted Diseases 18(2): 92-101.

McBride, D., Y. Terry-McElrath, J. Chriqui, et al. (2008). The Relationship between state methamphetamine precursor laws and trends in small toxic lab (STL) seizures. Washington, DC, U.S. Department of Justice.

Molitor, F., J. D. Ruiz, N. Flynn, et al. (1999). "Methamphetamine use and sexual and injection risk behaviors among out-of-treatment injection drug users." American Journal of Drug and Alcohol Abuse 25(3): 475-493.

Molitor, F., S. R. Truax, J. D. Ruiz, et al. (1998). "Association of methamphetamine use during sex with risky sexual behaviors and HIV infection among non-injection drug users." Western Journal of Medicine 168(2): 93-97.

National Institute on Drug Abuse (1998). "Comparing methamphetamine and cocaine." NIDA Notes 13(1).

Nonnemaker, J., M. Engelen and D. Shive (2011). "Are methamphetamine precursor control laws effective tools to fight the methamphetamine epidemic?" Health Economics 20(5): 519-531. 
Office of National Drug Policy Control (2001). What America's users spend on illegal drugs: 1988-2000. Washington, DC, Executive Office of the President.

Patterson, T. L., S. J. Semple, M. Fraga, et al. (2006). "Comparison of sexual and drug use behaviors between female sex workers in Tijuana and Ciudad Juarez, Mexico." Substance Use and Misuse 41(10-12): 1535-1549.

Rawson, R. A., A. Washton, C. P. Domier, et al. (2002). "Drugs and sexual effects: role of drug type and gender." Journal of Substance Abuse Treatment 22(2): 103-108.

Rolfs, R. T., M. R. Joesoef, E. F. Hendershot, et al. (1997). "A randomized trial of enhanced therapy for early syphilis in patients with and without human immunodeficiency virus infection. The Syphilis and HIV Study Group." New England Journal of Medicine 337(5): 307-314.

Rusch, M. L., K. C. Brouwer, R. Lozada, et al. (2010). "Distribution of sexually transmitted diseases and risk factors by work locations among female sex workers in Tijuana, Mexico." Sexually Transmitted Diseases 37(10): 608-614.

SAMHSA (2004). NSDUH 2002-2004 sample based prevalence estimates, Office of Applied Studies.

Semple, S. J., I. Grant and T. L. Patterson (2004). "Female methamphetamine users: social characteristics and sexual risk behavior." Women and Health 40(3): 35-50.

Semple, S. J., S. A. Strathdee, J. Zians, et al. (2011). "Correlates of trading sex for methamphetamine in a sample of HIV-negative heterosexual methamphetamine users." Journal of Psychoactive Drugs 43(2): 79-88.

Shoptaw, S. and C. J. Reback (2007). "Methamphetamine use and infectious disease-related behaviors in men who have sex with men: implications for interventions." Addiction 102 Suppl 1: 130-135.

Spinola, S. M., A. Orazi, J. N. Arno, et al. (1996). "Haemophilus ducreyi elicits a cutaneous infiltrate of CD4 cells during experimental human infection." Journal of Infectious Diseases 173(2): 394-402.

Sterk, C. E. (1999). Fast lives: women who use crack cocaine. Philadelphia, PA, Temple University Press.

Sterk, C. E. (2000). Tricking and tripping: prostitution in the era of AIDS. Putnam Valley, NY, Social Change Press.

Subcommittee on Crime of the Committee of the Judiciary (1995). Rising scourge of methamphetamine in America, House of Representatives, 104th Congress, First Session. 
Taylor, M. M., G. Aynalem, L. V. Smith, et al. (2007). "Methamphetamine use and sexual risk behaviours among men who have sex with men diagnosed with early syphilis in Los Angeles County." International Journal of STD and AIDS 18(2): 93-97.

Thiede, H., L. A. Valleroy, D. A. MacKellar, et al. (2003). "Regional patterns and correlates of substance use among young men who have sex with men in 7 US urban areas." American Journal of Public Health 93(11): 1915-1921.

U.S. v. Prather (2000). 205 F.3d 1265, United States Court of Appeals, Eleventh Circuit.

United States Drug Enforcement Agency (1997). Temporary Exemption From Chemical Registration for Distributors of Pseudoephedrine and Phenylpropanolamine Products. F. Register. 62: 53959-53960.

Wolfers, J. (2006). "Did unilateral divorce laws raise divorce rates? A reconciliation and new results." American Economic Review 96(5): 1802-1820.

Wong, W., J. K. Chaw, C. K. Kent, et al. (2005). "Risk factors for early syphilis among gay and bisexual men seen in an STD clinic: San Francisco, 2002-2003." Sexually Transmitted Diseases 32(7): 458-463.

Wooldridge, J. (2002). Econometric Analysis of Cross Section and Panel Data. Cambridge, MA, The MIT Press.

Zule, W. A., E. C. Costenbader, W. J. Meyer, Jr., et al. (2007). "Methamphetamine use and risky sexual behaviors during heterosexual encounters." Sexually Transmitted Diseases 34(9): 689-694. 


\section{Figure 1 \\ Syphilis Diagnoses and Meth-Related Hospital Admissions California 1994 to 2000}
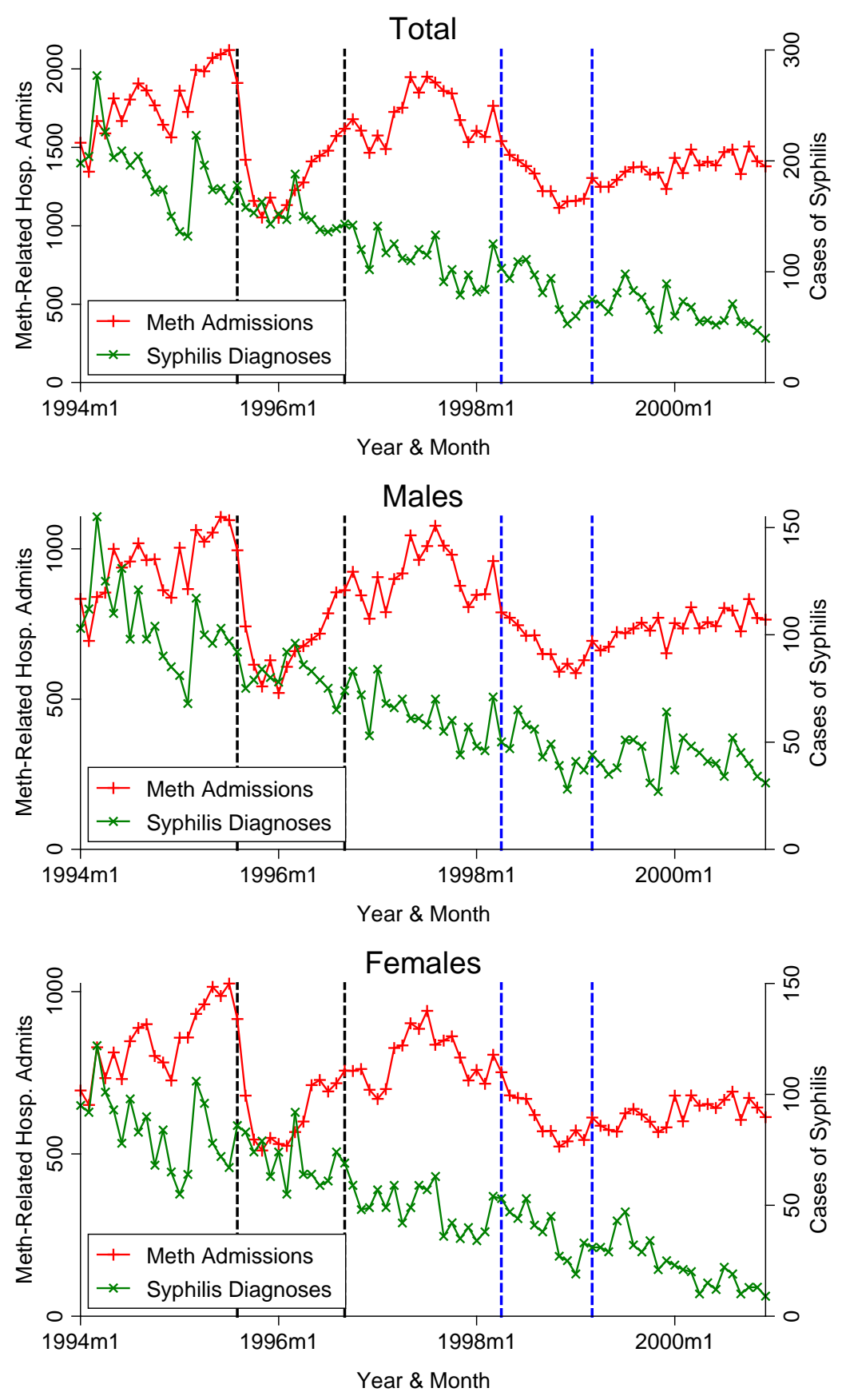

Notes:

Data from the California Department of Public Health and the California Office of Statewide Health Planning and Development. The red lines (marked with +'s) represent the total number of amphetaminerelated hospital admissions in California in each month, and the green lines (marked with x's) represent the total number of syphilis diagnoses in California in each month. The vertical black dashed lines mark August 1995 and September 1996, the time period of the first shock, and the vertical blue dashed lines mark April 1998 and March 1999, the time period of the second shock. 


\section{Table 1}

Summary Statistics

$\frac{\text { Total }}{\text { Mean }} \stackrel{\text { Men }}{\text { Std. Dev }}$ Mean Std. Dev

\begin{tabular}{c} 
Women \\
Mean Std. Dev \\
\hline
\end{tabular}

\section{Panel A: 1994 to 1997}

Syphilis Rate

Meth Admits Rate

Alcohol Admits Rate

Cannabis Admits Rate

Heroin Admits Rate

Cocaine Admits Rate

\% Population Male

\% Population Hispanic

Pop Density in 100s/sq. mile

\% Population Age Under

\% Population Age 18-39

Num

\section{Panel B: 1997 to 2000}

Syphilis Rate

Meth Admits Rate

Alcohol Admits Rate

Cannabis Admits Rate

Heroin Admits Rate

Cocaine Admits Rate

\% Population Male

\% Population Black

\% Population Hispanic

Pop Density in 100s/sq. mile

\% Population Age Under 18

\% Population Age 18-39
\% Population Black

0.180
5.604
30.101
3.375
4.326
2.700
50.584
3.742
20.865
5.997
27.536
31.247

2784

$\begin{array}{rr}0.100 & 0.310 \\ 4.833 & 4.618 \\ 31.215 & 15.566 \\ 3.997 & 5.036 \\ 4.779 & 4.069 \\ 2.463 & 3.440 \\ 50.636 & 2.325 \\ 3.814 & 3.848 \\ 22.388 & 15.071 \\ 6.213 & 22.117 \\ 26.495 & 4.007 \\ 30.138 & 5.261\end{array}$

2784

$$
0.471
$$

$$
4.966
$$

14.761

4.013

3.819

3.077

2.036

3.842

14.368

21.529

3.903

4.959

0.201
5.590
41.585
3.382
4.800
3.025
50.584
3.742
20.865
5.997
27.536
31.247

0.599

5.573

21.809

4.331

4.793

3.755

2.036

3.842

14.368

21.529

3.903

4.959

2784

\begin{abstract}
0.117
\end{abstract}
4.803

42.866

3.972

5.001

2.836

50.636

3.814

22.388

6.213

26.495

30.138

2784
0.156

5.633

18.518

3.383

3.848

2.372

50.584

3.742

20.865

5.997

27.536

31.247

2784

Num

0.388
4.850
22.323
5.439
4.990
3.824
2.325
3.848
15.071
22.117
4.007
5.261

0.388
4.850

0.083

4.875

19.462

4.041

4.560

2.092

50.636

3.814

22.388

6.213

26.495

30.138

2784

\section{Notes:}

Data from the California Department of Public Health, the California Office of Statewide Health Planning and Development, the U.S. Census, and the National Center for Health Statistics. 
Table 2

First Stage Regression Results of Effects of Methamphetamine Shock on Methamphetamine Consumption 1994 to 1997

Shock 95: 8/95-9/96

Log Alcohol Admits Rate

Log Cannabis Admits Rate

Log Heroin Admits Rate

Log Cocaine Admits Rate

\% Population Male

\% Population Black

\% Population Hispanic

Pop Density in 100s/sq. mile

\% Population Age Under 18

\% Population Age 18-39

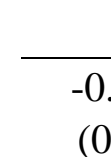

$(0.02)$

$0.099 * *$

(0.04)

$0.210 * * *$

(0.02)

0.033

(0.03)

$0.157 * * *$

(0.02)

0.268

(0.11)

$-0.248 * * *$

(0.09)

0.030

(0.03)

$-0.051 * *$

(0.02)

0.085

(0.07)

0.024

(0.07)

Num

R-Squared

F-Stat

2784
0.8803

95.38
Males

$-0.316$

(0.02)

$0.137 * * *$

(0.05)

$0.172 * * *$

(0.02)

0.041

(0.03)

$0.109 * * *$

(0.02)

$0.290 * *$

(0.11)

$-0.186 * *$

(0.07)

0.032

(0.03)

$-0.055 * *$

(0.03)

0.105

(0.08)

$-0.029$

(0.08)

2784

0.8242

173.02
Females

$-0.265 * * *$

(0.02)

$0.124 * * *$

(0.04)

$0.172 * * *$

(0.03)

$0.056 * *$

(0.02)

$0.144 * * *$

(0.02)

0.173

(0.11)

$-0.307 * *$

(0.12)

0.018

(0.04)

$-0.014$

(0.03)

0.026

(0.09)

0.133

(0.08)

2784
0.8401
150.31

\section{Notes:}

Data from the California Department of Public Health, the California Office of Statewide Health Planning and Development, the U.S. Census, and the National Center for Health Statistics. The dependent variable in all specifications is the log of the amphetamine-admission rate, defined as the number of amphetamine-related hospital admissions in a county and month +1 per 100,000 people. Coefficients represent semi-elasticities, and coefficients pertaining to indicator variables are transformed by $\exp [\beta]-1$. Standard errors, shown in parentheses, are clustered at the county level. In addition to the coefficients shown, all models include county, year and month fixed effects. Stars denote statistical significance: * Significant at $10 \%$; ** significant at 5\%; *** significant at $1 \%$. 
Table 3

First Stage Regression Results of Dynamic Effects of Methamphetamine Shock on Methamphetamine Consumption 1994 to 1997

\begin{tabular}{|c|c|c|c|}
\hline & Total & Males & Females \\
\hline Shock 95: 6/95-7/95 & $\begin{array}{l}0.012 \\
(0.02)\end{array}$ & $\begin{array}{l}0.004 \\
(0.04)\end{array}$ & $\begin{array}{r}0.025 \\
(0.03)\end{array}$ \\
\hline Shock 95: 8/95-9/95 & $\begin{array}{l}-0.250 * * * \\
(0.03)\end{array}$ & $\begin{array}{l}-0.276 \text { *** } \\
(0.03)\end{array}$ & $\begin{array}{l}-0.217 * * * \\
(0.03)\end{array}$ \\
\hline Shock 95: 10/95-1/96 & $\begin{array}{l}-0.412 * * * \\
(0.02)\end{array}$ & $\begin{array}{l}-0.435 * * * \\
(0.03)\end{array}$ & $\begin{array}{l}-0.369 * * * \\
(0.03)\end{array}$ \\
\hline Shock 95: 2/96-5/96 & $\begin{array}{l}-0.294 * * * \\
(0.04)\end{array}$ & $\begin{array}{l}-0.252 \text { *** } \\
(0.05)\end{array}$ & $\begin{array}{l}-0.333 * * * \\
(0.07)\end{array}$ \\
\hline Shock 95: 6/96-9/96 & $\begin{array}{l}-0.222 * * * \\
(0.06)\end{array}$ & $\begin{array}{l}-0.199 \text { *** } \\
(0.05)\end{array}$ & $\begin{array}{l}-0.243 * * \\
(0.09)\end{array}$ \\
\hline Shock 95: 10/96-1/97 & $\begin{array}{l}-0.101 * \\
(0.05)\end{array}$ & $\begin{array}{r}-0.051 \\
(0.06)\end{array}$ & $\begin{array}{r}-0.150 \\
(0.09)\end{array}$ \\
\hline Shock 95: Post 1/97 & $\begin{array}{r}-0.051 \\
(0.06)\end{array}$ & $\begin{array}{r}-0.039 \\
(0.08)\end{array}$ & $\begin{array}{r}-0.076 \\
(0.10)\end{array}$ \\
\hline Log Alcohol Admits Rate & $\begin{array}{l}0.116 * * \\
(0.05)\end{array}$ & $\begin{array}{l}0.153 \text { *** } \\
(0.05)\end{array}$ & $\begin{array}{l}0.128 \text { *** } \\
(0.04)\end{array}$ \\
\hline Log Cannabis Admits Rate & $\begin{array}{l}0.204 \text { *** } \\
(0.02)\end{array}$ & $\begin{array}{l}0.171 \text { *** } \\
(0.02)\end{array}$ & $\begin{array}{l}0.167 \text { *** } \\
(0.03)\end{array}$ \\
\hline Log Heroin Admits Rate & $\begin{array}{l}0.048 \text { * } \\
(0.03)\end{array}$ & $\begin{array}{l}0.051 * * \\
(0.02)\end{array}$ & $\begin{array}{l}0.061 \text { *** } \\
(0.02)\end{array}$ \\
\hline Log Cocaine Admits Rate & $\begin{array}{l}0.142 * * * \\
(0.02)\end{array}$ & $\begin{array}{l}0.101 \text { *** } \\
(0.02)\end{array}$ & $\begin{array}{l}0.134 \text { *** } \\
(0.02)\end{array}$ \\
\hline \% Population Male & $\begin{array}{l}0.330 * * * \\
(0.11)\end{array}$ & $\begin{array}{l}0.349 * * * \\
(0.11)\end{array}$ & $\begin{array}{l}0.234 \text { ** } \\
(0.11)\end{array}$ \\
\hline \% Population Black & $\begin{array}{l}-0.236 * * * \\
(0.09)\end{array}$ & $\begin{array}{l}-0.175 * * \\
(0.07)\end{array}$ & $\begin{array}{l}-0.295 * * \\
(0.12)\end{array}$ \\
\hline \% Population Hispanic & $\begin{array}{l}0.018 \\
(0.03)\end{array}$ & $\begin{array}{l}0.021 \\
(0.04)\end{array}$ & $\begin{array}{l}0.007 \\
(0.04)\end{array}$ \\
\hline Pop Density in 100s/sq. mile & $\begin{array}{l}-0.055 * * \\
(0.03)\end{array}$ & $\begin{array}{l}-0.059 * \\
(0.03)\end{array}$ & $\begin{array}{r}-0.017 \\
(0.03)\end{array}$ \\
\hline \% Population Age Under 18 & $\begin{array}{l}0.162 * * \\
(0.07)\end{array}$ & $\begin{array}{l}0.176 * * \\
(0.08)\end{array}$ & $\begin{array}{r}0.098 \\
(0.09)\end{array}$ \\
\hline \% Population Age 18-39 & $\begin{array}{r}0.018 \\
(0.07)\end{array}$ & $\begin{array}{r}-0.036 \\
(0.08)\end{array}$ & $\begin{array}{r}0.125 \\
(0.08)\end{array}$ \\
\hline Num & 2784 & 2784 & 2784 \\
\hline R-Squared & 0.8873 & 0.8333 & 0.8442 \\
\hline F-Stat & 219.29 & 252.68 & 225.33 \\
\hline
\end{tabular}

\section{Notes:}

Data from the California Department of Public Health, the California Office of Statewide Health Planning and Development, the U.S. Census, and the National Center for Health Statistics. The dependent variable in all specifications is the log of the amphetamine-admission rate, defined as the number of amphetaminerelated hospital admissions in a county and month +1 per 100,000 people. Coefficients represent semielasticities, and coefficients pertaining to indicator variables are transformed by $\exp [\beta]-1$. Standard errors, shown in parentheses, are clustered at the county level. In addition to the coefficients shown, all models include county, year and month fixed effects. Stars denote statistical significance: * Significant at $10 \%$; ** significant at $5 \%$; *** significant at $1 \%$. 


\section{Table 4 \\ IV Regression Results of Effects of Methamphetamine Consumption on Syphilis Transmission 1994 to 1997}

\begin{tabular}{|c|c|c|c|c|c|c|}
\hline & Total & Males & Females & Total & Males & Females \\
\hline Log Meth Admits Rate & $\begin{array}{r}-0.225 \\
(0.17)\end{array}$ & $\begin{array}{c}0.004 \\
(0.18)\end{array}$ & $\begin{array}{l}-0.556^{* * *} \\
(0.18)\end{array}$ & $\begin{array}{l}-0.212 \\
(0.15)\end{array}$ & $\begin{array}{r}-0.010 \\
(0.15)\end{array}$ & $\begin{array}{l}-0.502^{* * *} \\
(0.18)\end{array}$ \\
\hline Lagged Log Syphilis Rate & & & & $\begin{array}{l}0.220^{* * *} \\
(0.07)\end{array}$ & $\begin{array}{l}0.196 \text { *** } \\
(0.04)\end{array}$ & $\begin{array}{l}0.176 \text { ** } \\
(0.08)\end{array}$ \\
\hline Log Alcohol Admits Rate & $\begin{array}{r}-0.040 \\
(0.12)\end{array}$ & $\begin{array}{l}0.053 \\
(0.09)\end{array}$ & $\begin{array}{r}-0.014 \\
(0.05)\end{array}$ & $\begin{array}{r}-0.035 \\
(0.13)\end{array}$ & $\begin{array}{l}0.052 \\
(0.08)\end{array}$ & $\begin{array}{l}-0.002 \\
(0.05)\end{array}$ \\
\hline Log Cannabis Admits Rate & $\begin{array}{c}0.053 \\
(0.07)\end{array}$ & $\begin{array}{r}-0.048 \\
(0.03)\end{array}$ & $\begin{array}{c}0.074 \\
(0.06)\end{array}$ & $\begin{array}{c}0.068 \\
(0.07)\end{array}$ & $\begin{array}{r}-0.031 \\
(0.03)\end{array}$ & $\begin{array}{r}0.070 \\
(0.05)\end{array}$ \\
\hline Log Heroin Admits Rate & $\begin{array}{l}0.000 \\
(0.04)\end{array}$ & $\begin{array}{l}0.012 \\
(0.05)\end{array}$ & $\begin{array}{l}0.030 \\
(0.05)\end{array}$ & $\begin{array}{r}-0.008 \\
(0.04)\end{array}$ & $\begin{array}{l}0.010 \\
(0.04)\end{array}$ & $\begin{array}{l}0.025 \\
(0.05)\end{array}$ \\
\hline Log Cocaine Admits Rate & $\begin{array}{r}-0.021 \\
(0.07)\end{array}$ & $\begin{array}{r}-0.051 \\
(0.05)\end{array}$ & $\begin{array}{l}0.112 \\
(0.07)\end{array}$ & $\begin{array}{r}-0.023 \\
(0.07)\end{array}$ & $\begin{array}{r}-0.061 \\
(0.05)\end{array}$ & $\begin{array}{l}0.119 \text { * } \\
(0.07)\end{array}$ \\
\hline \% Population Male & $\begin{array}{l}0.464 \\
(0.45)\end{array}$ & $\begin{array}{l}0.303 \\
(0.41)\end{array}$ & $\begin{array}{l}0.505 \\
(0.43)\end{array}$ & $\begin{array}{c}0.373 \\
(0.36)\end{array}$ & $\begin{array}{c}0.249 \\
(0.33)\end{array}$ & $\begin{array}{c}0.412 \\
(0.36)\end{array}$ \\
\hline \% Population Black & $\begin{array}{l}0.043 \\
(0.24)\end{array}$ & $\begin{array}{l}0.263 * \\
(0.15)\end{array}$ & $\begin{array}{r}-0.007 \\
(0.28)\end{array}$ & $\begin{array}{l}0.010 \\
(0.18)\end{array}$ & $\begin{array}{l}0.206 \\
(0.12)\end{array}$ & $\begin{array}{r}-0.034 \\
(0.23)\end{array}$ \\
\hline \% Population Hispanic & $\begin{array}{c}-0.117 \\
(0.08)\end{array}$ & $\begin{array}{c}-0.162 * \\
(0.09)\end{array}$ & $\begin{array}{r}-0.026 \\
(0.07)\end{array}$ & $\begin{array}{r}-0.094 \\
(0.07)\end{array}$ & $\begin{array}{c}-0.137 \text { * } \\
(0.07)\end{array}$ & $\begin{array}{r}-0.019 \\
(0.06)\end{array}$ \\
\hline Pop Density in 100s/sq. mile & $\begin{array}{r}-0.135 \\
(0.09)\end{array}$ & $\begin{array}{r}-0.027 \\
(0.05)\end{array}$ & $\begin{array}{r}-0.108 \\
(0.12)\end{array}$ & $\begin{array}{l}-0.111 \\
(0.08)\end{array}$ & $\begin{array}{r}-0.025 \\
(0.04)\end{array}$ & $\begin{array}{r}-0.091 \\
(0.10)\end{array}$ \\
\hline \% Population Age Under 18 & $\begin{array}{l}0.063 \\
(0.23)\end{array}$ & $\begin{array}{l}0.109 \\
(0.19)\end{array}$ & $\begin{array}{r}-0.073 \\
(0.23)\end{array}$ & $\begin{array}{r}0.035 \\
(0.18)\end{array}$ & $\begin{array}{l}0.090 \\
(0.15)\end{array}$ & $\begin{array}{r}-0.090 \\
(0.19)\end{array}$ \\
\hline \% Population Age 18-39 & $\begin{array}{l}0.502 \\
(0.23)\end{array}$ & $\begin{array}{l}0.360 \text { * } \\
(0.20)\end{array}$ & $\begin{array}{l}0.459 \text { * } \\
(0.26)\end{array}$ & $\begin{array}{l}0.396^{* *} \\
(0.18)\end{array}$ & $\begin{array}{l}0.298 \text { * } \\
(0.17)\end{array}$ & $\begin{array}{l}0.383^{*} \\
(0.22)\end{array}$ \\
\hline Num & 2784 & 2784 & 2784 & 2784 & 2784 & 2784 \\
\hline Partial R-Squared & 0.2124 & 0.1804 & 0.1102 & 0.2126 & 0.1802 & 0.1105 \\
\hline KP F-Stat & 231.88 & 189.06 & 203.42 & 234.49 & 195.64 & 195.40 \\
\hline KP P-Value & 0.00 & 0.00 & 0.00 & 0.00 & 0.00 & 0.00 \\
\hline Hausman P-Value & 0.18 & 0.90 & 0.02 & 0.20 & 0.85 & 0.03 \\
\hline
\end{tabular}

\section{Notes:}

Data from the California Department of Public Health, the California Office of Statewide Health Planning and Development, the U.S. Census, and the National Center for Health Statistics. The dependent variable in all specifications is the log of the number of syphilis diagnoses in a county and month +1 per 100,000 people. Standard errors, shown in parentheses, are clustered at the county level. In addition to the coefficients shown, all models include county, year and month fixed effects. Stars denote statistical significance: * Significant at $10 \%$; ** significant at $5 \%$; *** significant at $1 \%$. 


\section{Table 5}

Fixed Effects Poisson Regression Results of Effects of Methamphetamine Consumption on Syphilis Transmission 1994 to 1997

\begin{tabular}{|c|c|c|c|c|c|c|}
\hline & Total & Males & Females & Total & Males & Females \\
\hline Log Meth Admits Rate & $\begin{array}{c}0.011 \\
(0.24)\end{array}$ & $\begin{array}{c}0.176 \\
(0.32)\end{array}$ & $\begin{array}{r}-0.199 \\
(0.19)\end{array}$ & $\begin{array}{c}0.124 \\
(0.19)\end{array}$ & $\begin{array}{c}0.264 \\
(0.30)\end{array}$ & $\begin{array}{l}-0.187 \\
(0.18)\end{array}$ \\
\hline Lagged Syphilis Count & & & & $\begin{array}{l}0.003 * * \\
(0.00)\end{array}$ & $\begin{array}{l}0.005 * * * \\
(0.00)\end{array}$ & $\begin{array}{l}0.001 \\
(0.00)\end{array}$ \\
\hline Log Alcohol Admits Rate & $\begin{array}{r}-0.121 \\
(0.30)\end{array}$ & $\begin{array}{c}0.155 \\
(0.27)\end{array}$ & $\begin{array}{r}-0.115 \\
(0.16)\end{array}$ & $\begin{array}{c}-0.117 \\
(0.31)\end{array}$ & $\begin{array}{c}0.132 \\
(0.28)\end{array}$ & $\begin{array}{c}-0.113 \\
(0.16)\end{array}$ \\
\hline Log Cannabis Admits Rate & $\begin{array}{l}-0.126 \\
(0.09)\end{array}$ & $\begin{array}{r}-0.068 \\
(0.08)\end{array}$ & $\begin{array}{l}-0.129 \\
(0.10)\end{array}$ & $\begin{array}{l}-0.127 \\
(0.09)\end{array}$ & $\begin{array}{l}-0.062 \\
(0.08)\end{array}$ & $\begin{array}{l}-0.130 \\
(0.10)\end{array}$ \\
\hline Log Heroin Admits Rate & $\begin{array}{l}0.049 \\
(0.10)\end{array}$ & $\begin{array}{l}0.061 \\
(0.16)\end{array}$ & $\begin{array}{l}0.040 \\
(0.14)\end{array}$ & $\begin{array}{l}0.037 \\
(0.10)\end{array}$ & $\begin{array}{l}0.059 \\
(0.16)\end{array}$ & $\begin{array}{l}0.039 \\
(0.14)\end{array}$ \\
\hline Log Cocaine Admits Rate & $\begin{array}{l}0.057 \\
(0.15)\end{array}$ & $\begin{array}{l}-0.047 \\
(0.15)\end{array}$ & $\begin{array}{l}0.094 \\
(0.14)\end{array}$ & $\begin{array}{l}0.032 \\
(0.15)\end{array}$ & $\begin{array}{l}-0.069 \\
(0.15)\end{array}$ & $\begin{array}{l}0.093 \\
(0.14)\end{array}$ \\
\hline \% Population Male & $\begin{array}{l}1.416^{* *} \\
(0.63)\end{array}$ & $\begin{array}{l}1.410 \\
(1.05)\end{array}$ & $\begin{array}{l}1.399 * * * \\
(0.39)\end{array}$ & $\begin{array}{l}1.244 \text { ** } \\
(0.62)\end{array}$ & $\begin{array}{l}1.232 \\
(1.05)\end{array}$ & $\begin{array}{l}1.384 \text { *** } \\
(0.39)\end{array}$ \\
\hline \% Population Black & $\begin{array}{l}0.087 \\
(0.23)\end{array}$ & $\begin{array}{l}0.285 \\
(0.24)\end{array}$ & $\begin{array}{l}-0.159 \\
(0.31)\end{array}$ & $\begin{array}{l}-0.007 \\
(0.29)\end{array}$ & $\begin{array}{l}0.188 \\
(0.26)\end{array}$ & $\begin{array}{l}-0.166 \\
(0.33)\end{array}$ \\
\hline \% Population Hispanic & $\begin{array}{l}-0.207 \\
(0.23)\end{array}$ & $\begin{array}{l}-0.403 \\
(0.30)\end{array}$ & $\begin{array}{l}0.031 \\
(0.22)\end{array}$ & $\begin{array}{l}-0.203 \\
(0.23)\end{array}$ & $\begin{array}{l}-0.398 \\
(0.29)\end{array}$ & $\begin{array}{l}0.031 \\
(0.22)\end{array}$ \\
\hline Pop Density in 100s/sq. mile & $\begin{array}{l}-0.239 * \\
(0.14)\end{array}$ & $\begin{array}{l}-0.254 \\
(0.17)\end{array}$ & $\begin{array}{l}-0.234 \\
(0.22)\end{array}$ & $\begin{array}{c}-0.256 * \\
(0.14)\end{array}$ & $\begin{array}{l}-0.272 \\
(0.17)\end{array}$ & $\begin{array}{l}-0.236 \\
(0.23)\end{array}$ \\
\hline \% Population Age Under 18 & $\begin{array}{l}1.744^{* * *} \\
(0.25)\end{array}$ & $\begin{array}{l}1.678 * * * \\
(0.32)\end{array}$ & $\begin{array}{l}1.860 * * * \\
(0.27)\end{array}$ & $\begin{array}{l}1.847^{* * *} \\
(0.26)\end{array}$ & $\begin{array}{l}1.761 * * * \\
(0.31)\end{array}$ & $\begin{array}{l}1.872 \text { *** } \\
(0.27)\end{array}$ \\
\hline \% Population Age 18-39 & $\begin{array}{l}1.836 \text { *** } \\
(0.32)\end{array}$ & $\begin{array}{l}1.700 * * * \\
(0.41)\end{array}$ & $\begin{array}{l}2.071 * * * \\
(0.28)\end{array}$ & $\begin{array}{l}1.884 * * * \\
(0.32)\end{array}$ & $\begin{array}{l}1.756 * * * \\
(0.40)\end{array}$ & $\begin{array}{l}2.075 * * * \\
(0.28)\end{array}$ \\
\hline Num & 2208 & 1968 & 2016 & 2208 & 1968 & 2016 \\
\hline
\end{tabular}

Notes:

Data from the California Department of Public Health, the California Office of Statewide Health Planning and Development, the U.S. Census, and the National Center for Health Statistics. The dependent variable in all specifications is the number of syphilis diagnoses in a county and month. Standard errors, shown in parentheses, are clustered at the county level. In addition to the coefficients shown, all models include the residuals from the first stage regression and county, year and month fixed effects. Stars denote statistical significance: * Significant at $10 \%$; ** significant at $5 \%$; *** significant at $1 \%$. 


\section{Table 6 \\ First Stage Regression Results of Effects of Methamphetamine Shock on Methamphetamine Consumption 1997 to 2000}

\begin{tabular}{|c|c|c|c|c|c|c|}
\hline \multirow[b]{2}{*}{ Shock 98: 4/98-3/99 } & \multicolumn{2}{|c|}{ Total } & \multicolumn{2}{|c|}{ Males } & \multicolumn{2}{|c|}{ Females } \\
\hline & $\begin{array}{r}-0.151 \\
(0.01)\end{array}$ & $* * *$ & $\begin{array}{r}-0.168 \\
(0.02)\end{array}$ & $* * *$ & $\begin{array}{r}-0.123 \\
(0.02)\end{array}$ & $* * *$ \\
\hline Log Alcohol Admits Rate & $\begin{array}{l}0.235 \\
(0.06)\end{array}$ & $* * *$ & $\begin{array}{c}0.256 \\
(0.06)\end{array}$ & $* * *$ & $\begin{array}{c}0.134 \\
(0.04)\end{array}$ & $* * *$ \\
\hline Log Cannabis Admits Rate & $\begin{array}{l}0.248 \\
(0.03)\end{array}$ & $* * *$ & $\begin{array}{l}0.201 \\
(0.02)\end{array}$ & $* * *$ & $\begin{array}{l}0.205 \\
(0.03)\end{array}$ & $* * *$ \\
\hline Log Heroin Admits Rate & $\begin{array}{l}0.076 \\
(0.02)\end{array}$ & $* * *$ & $\begin{array}{l}0.058 \\
(0.03)\end{array}$ & $* *$ & $\begin{array}{c}0.112 \\
(0.02)\end{array}$ & $* * *$ \\
\hline Log Cocaine Admits Rate & $\begin{array}{l}0.105 \\
(0.03)\end{array}$ & $* * *$ & $\begin{array}{c}0.133 \\
(0.03)\end{array}$ & $* * *$ & $\begin{array}{c}0.111 \\
(0.03)\end{array}$ & $* * *$ \\
\hline \% Population Male & $\begin{array}{r}-0.064 \\
(0.13)\end{array}$ & & $\begin{array}{r}-0.032 \\
(0.09)\end{array}$ & & $\begin{array}{r}-0.048 \\
(0.16)\end{array}$ & \\
\hline \% Population Black & $\begin{array}{r}-0.033 \\
(0.05)\end{array}$ & & $\begin{array}{r}-0.038 \\
(0.06)\end{array}$ & & $\begin{array}{c}0.012 \\
(0.07)\end{array}$ & \\
\hline \% Population Hispanic & $\begin{array}{l}0.046 \\
(0.04)\end{array}$ & & $\begin{array}{l}0.067 \\
(0.03)\end{array}$ & $*$ & $\begin{array}{l}0.010 \\
(0.05)\end{array}$ & \\
\hline Pop Density in 100s/sq. mile & $\begin{array}{l}0.046 \\
(0.03)\end{array}$ & & $\begin{array}{c}0.064 \\
(0.03)\end{array}$ & $* *$ & $\begin{array}{l}0.031 \\
(0.05)\end{array}$ & \\
\hline \% Population Age Under 18 & $\begin{array}{r}-0.169 \\
(0.11)\end{array}$ & & $\begin{array}{r}-0.162 \\
(0.10)\end{array}$ & & $\begin{array}{r}-0.211 \\
(0.13)\end{array}$ & \\
\hline \% Population Age 18-39 & $\begin{array}{r}-0.011 \\
(0.07)\end{array}$ & & $\begin{array}{r}-0.021 \\
(0.07)\end{array}$ & & $\begin{array}{r}-0.018 \\
(0.08)\end{array}$ & \\
\hline Num & 2784 & & 2784 & & 2784 & \\
\hline R-Squared & 0.8652 & & 0.8112 & & 0.8237 & \\
\hline F-Stat & 215.9706 & & 114.7889 & & 108.4021 & \\
\hline
\end{tabular}

\section{Notes:}

Data from the California Department of Public Health, the California Office of Statewide Health Planning and Development, the U.S. Census, and the National Center for Health Statistics. The dependent variable in all specifications is the log of the amphetamine-admission rate, defined as the number of amphetaminerelated hospital admissions in a county and month +1 per 100,000 people. Coefficients represent semielasticities, and coefficients pertaining to indicator variables are transformed by exp[ $\beta]-1$. Standard errors, shown in parentheses, are clustered at the county level. In addition to the coefficients shown, all models include county, year and month fixed effects. Stars denote statistical significance: * Significant at $10 \%$; ** significant at $5 \%$; *** significant at $1 \%$. 


\section{Table 7 \\ First Stage Regression Results of Dynamic Effects of Methamphetamine Shock on Methamphetamine Consumption 1997 to 2000}

\begin{tabular}{|c|c|c|c|}
\hline & Total & Males & Females \\
\hline Shock 98: 2/98-3/98 & $\begin{array}{l}0.017 \\
(0.05)\end{array}$ & $\begin{array}{l}0.074 \\
(0.10)\end{array}$ & $\begin{array}{l}-0.063 \\
(0.04)\end{array}$ \\
\hline Shock 98: 4/98-5/98 & $\begin{array}{l}-0.162 * * * \\
(0.05)\end{array}$ & $\begin{array}{l}-0.132 * * \\
(0.05)\end{array}$ & $\begin{array}{l}-0.196 \text { *** } \\
(0.05)\end{array}$ \\
\hline Shock 98: 6/98-9/98 & $\begin{array}{l}-0.262 * * * \\
(0.03)\end{array}$ & $\begin{array}{l}-0.236 * * * \\
(0.03)\end{array}$ & $\begin{array}{l}-0.288 * * * \\
(0.03)\end{array}$ \\
\hline Shock 98: 10/98-1/99 & $\begin{array}{l}-0.308 * * * \\
(0.02)\end{array}$ & $\begin{array}{l}-0.276 \text { *** } \\
(0.03)\end{array}$ & $\begin{array}{l}-0.351 \text { *** } \\
(0.03)\end{array}$ \\
\hline Shock 98: 2/99-3/99 & $\begin{array}{l}-0.262 * * * \\
(0.03)\end{array}$ & $\begin{array}{l}-0.178 * * * \\
(0.06)\end{array}$ & $\begin{array}{l}-0.374 \text { *** } \\
(0.05)\end{array}$ \\
\hline Shock 98: 4/99-6/99 & $\begin{array}{l}-0.287 * * * \\
(0.04)\end{array}$ & $\begin{array}{l}-0.168 * * * \\
(0.05)\end{array}$ & $\begin{array}{l}-0.427 * * * \\
(0.07)\end{array}$ \\
\hline Shock 98: Post 6/99 & $\begin{array}{l}-0.251 \text { *** } \\
(0.03)\end{array}$ & $\begin{array}{l}-0.159 * * * \\
(0.05)\end{array}$ & $\begin{array}{l}-0.368 * * * \\
(0.06)\end{array}$ \\
\hline Log Alcohol Admits Rate & $\begin{array}{l}0.237 * * * \\
(0.06)\end{array}$ & $\begin{array}{l}0.259 \text { *** } \\
(0.06)\end{array}$ & $\begin{array}{l}0.133 \text { *** } \\
(0.04)\end{array}$ \\
\hline Log Cannabis Admits Rate & $\begin{array}{l}0.233 \text { *** } \\
(0.03)\end{array}$ & $\begin{array}{l}0.191 \text { *** } \\
(0.02)\end{array}$ & $\begin{array}{l}0.199 \text { *** } \\
(0.03)\end{array}$ \\
\hline Log Heroin Admits Rate & $\begin{array}{l}0.070 * * * \\
(0.02)\end{array}$ & $\begin{array}{l}0.058 * * \\
(0.03)\end{array}$ & $\begin{array}{l}0.099 * * * \\
(0.02)\end{array}$ \\
\hline Log Cocaine Admits Rate & $\begin{array}{l}0.114 \text { *** } \\
(0.03)\end{array}$ & $\begin{array}{l}0.140 \text { *** } \\
(0.03)\end{array}$ & $\begin{array}{l}0.115 \text { *** } \\
(0.03)\end{array}$ \\
\hline \% Population Male & $\begin{array}{r}-0.072 \\
(0.13)\end{array}$ & $\begin{array}{l}-0.038 \\
(0.09)\end{array}$ & $\begin{array}{r}-0.059 \\
(0.16)\end{array}$ \\
\hline \% Population Black & $\begin{array}{r}-0.031 \\
(0.05)\end{array}$ & $\begin{array}{r}-0.037 \\
(0.06)\end{array}$ & $\begin{array}{l}0.013 \\
(0.07)\end{array}$ \\
\hline \% Population Hispanic & $\begin{array}{l}0.046 \\
(0.04)\end{array}$ & $\begin{array}{l}0.067 * \\
(0.03)\end{array}$ & $\begin{array}{l}0.010 \\
(0.05)\end{array}$ \\
\hline Pop Density in 100s/sq. mile & $\begin{array}{l}0.045 \\
(0.03)\end{array}$ & $\begin{array}{l}0.062 * * \\
(0.03)\end{array}$ & $\begin{array}{l}0.030 \\
(0.05)\end{array}$ \\
\hline \% Population Age Under 18 & $\begin{array}{l}-0.171 \\
(0.11)\end{array}$ & $\begin{array}{r}-0.162 \\
(0.10)\end{array}$ & $\begin{array}{l}-0.213 * \\
(0.13)\end{array}$ \\
\hline \% Population Age 18-39 & $\begin{array}{l}-0.013 \\
(0.07)\end{array}$ & $\begin{array}{l}-0.022 \\
(0.07)\end{array}$ & $\begin{array}{l}-0.023 \\
(0.08)\end{array}$ \\
\hline Num & 2784 & 2784 & 2784 \\
\hline R-Squared & 0.8717 & 0.8161 & 0.8312 \\
\hline F-Stat & 326.8615 & 209.2448 & 682.9941 \\
\hline
\end{tabular}

Notes:

Data from the California Department of Public Health, the California Office of Statewide Health Planning and Development, the U.S. Census, and the National Center for Health Statistics. The dependent variable in all specifications is the log of the amphetamine-admission rate, defined as the number of amphetamine-related hospital admissions in a county and month +1 per 100,000 people. Coefficients represent semi-elasticities, and coefficients pertaining to indicator variables are transformed by $\exp [\beta]-1$. Standard errors, shown in parentheses, are clustered at the county level. In addition to the coefficients shown, all models include county, year and month fixed effects. Stars denote statistical significance: * Significant at $10 \%$; ** significant at $5 \%$; *** significant at $1 \%$. 


\section{Regression Results of Effects of Methamphetamine Consumption on Syphilis Transmission 1997 to 2000}

\begin{tabular}{|c|c|c|c|c|c|c|}
\hline & Total & Males & Females & Total & Males & Females \\
\hline Log Meth Admits Rate & $\begin{array}{l}-0.047 \\
(0.24)\end{array}$ & $\begin{array}{r}-0.078 \\
(0.20)\end{array}$ & $\begin{array}{l}0.000 \\
(0.21)\end{array}$ & $\begin{array}{l}0.011 \\
(0.21)\end{array}$ & $\begin{array}{l}-0.040 \\
(0.15)\end{array}$ & $\begin{array}{l}0.051 \\
(0.19)\end{array}$ \\
\hline Lagged Log Syphilis Rate & & & & $\begin{array}{l}0.254 * * * \\
(0.05)\end{array}$ & $\begin{array}{l}0.193 * * * \\
(0.05)\end{array}$ & $\begin{array}{l}0.239 \text { *** } \\
(0.07)\end{array}$ \\
\hline Log Alcohol Admits Rate & $\begin{array}{l}0.169 * \\
(0.10)\end{array}$ & $\begin{array}{l}0.295 * * * \\
(0.10)\end{array}$ & $\begin{array}{r}-0.084 \\
(0.06)\end{array}$ & $\begin{array}{l}0.182 * * \\
(0.09)\end{array}$ & $\begin{array}{l}0.296 * * * \\
(0.10)\end{array}$ & $\begin{array}{r}-0.068 \\
(0.05)\end{array}$ \\
\hline Log Cannabis Admits Rate & $\begin{array}{l}0.019 \\
(0.07)\end{array}$ & $\begin{array}{l}0.064 \\
(0.06)\end{array}$ & $\begin{array}{r}-0.015 \\
(0.04)\end{array}$ & $\begin{array}{l}-0.021 \\
(0.06)\end{array}$ & $\begin{array}{l}0.035 \\
(0.05)\end{array}$ & $\begin{array}{r}-0.033 \\
(0.04)\end{array}$ \\
\hline Log Heroin Admits Rate & $\begin{array}{r}-0.074 \\
(0.05)\end{array}$ & $\begin{array}{l}-0.130 * * \\
(0.06)\end{array}$ & $\begin{array}{r}-0.029 \\
(0.04)\end{array}$ & $\begin{array}{l}-0.069 \\
(0.04)\end{array}$ & $\begin{array}{l}-0.122 * * \\
(0.06)\end{array}$ & $\begin{array}{r}-0.025 \\
(0.03)\end{array}$ \\
\hline Log Cocaine Admits Rate & $\begin{array}{l}0.016 \\
(0.03)\end{array}$ & $\begin{array}{r}-0.018 \\
(0.04)\end{array}$ & $\begin{array}{l}0.054 \\
(0.05)\end{array}$ & $\begin{array}{l}0.000 \\
(0.03)\end{array}$ & $\begin{array}{r}-0.030 \\
(0.03)\end{array}$ & $\begin{array}{l}0.056 \\
(0.05)\end{array}$ \\
\hline \% Population Male & $\begin{array}{l}0.139 \\
(0.25)\end{array}$ & $\begin{array}{l}0.114 \\
(0.21)\end{array}$ & $\begin{array}{l}0.087 \\
(0.28)\end{array}$ & $\begin{array}{l}0.109 \\
(0.18)\end{array}$ & $\begin{array}{l}0.095 \\
(0.17)\end{array}$ & $\begin{array}{l}0.068 \\
(0.21)\end{array}$ \\
\hline \% Population Black & $\begin{array}{l}0.829 * * \\
(0.42)\end{array}$ & $\begin{array}{l}0.603 * * \\
(0.29)\end{array}$ & $\begin{array}{l}0.971 * \\
(0.54)\end{array}$ & $\begin{array}{l}0.623 * * \\
(0.31)\end{array}$ & $\begin{array}{l}0.489 * * \\
(0.23)\end{array}$ & $\begin{array}{l}0.740 * \\
(0.38)\end{array}$ \\
\hline \% Population Hispanic & $\begin{array}{l}0.024 \\
(0.13)\end{array}$ & $\begin{array}{r}-0.002 \\
(0.10)\end{array}$ & $\begin{array}{l}-0.062 \\
(0.13)\end{array}$ & $\begin{array}{l}0.009 \\
(0.09)\end{array}$ & $\begin{array}{r}-0.005 \\
(0.08)\end{array}$ & $\begin{array}{r}-0.055 \\
(0.10)\end{array}$ \\
\hline Pop Density in 100 s/sq. mile & $\begin{array}{l}0.384 \text { ** } \\
(0.20)\end{array}$ & $\begin{array}{l}0.348 \text { ** } \\
(0.15)\end{array}$ & $\begin{array}{l}0.082 \\
(0.21)\end{array}$ & $\begin{array}{l}0.278 * \\
(0.14)\end{array}$ & $\begin{array}{l}0.276 * * \\
(0.11)\end{array}$ & $\begin{array}{l}0.053 \\
(0.16)\end{array}$ \\
\hline \% Population Age Under 18 & $\begin{array}{l}-0.197 \\
(0.34)\end{array}$ & $\begin{array}{r}-0.083 \\
(0.28)\end{array}$ & $\begin{array}{r}-0.388 \\
(0.32)\end{array}$ & $\begin{array}{l}-0.127 \\
(0.25)\end{array}$ & $\begin{array}{r}-0.059 \\
(0.22)\end{array}$ & $\begin{array}{r}-0.275 \\
(0.24)\end{array}$ \\
\hline \% Population Age 18-39 & $\begin{array}{l}-0.530 \text { ** } \\
(0.26)\end{array}$ & $\begin{array}{l}-0.403 * \\
(0.21)\end{array}$ & $\begin{array}{l}-0.382 * \\
(0.22)\end{array}$ & $\begin{array}{l}-0.385 * * \\
(0.19)\end{array}$ & $\begin{array}{l}-0.324 * \\
(0.17)\end{array}$ & $\begin{array}{r}-0.280 \\
(0.18)\end{array}$ \\
\hline Num & 2784 & 2784 & 2784 & 2784 & 2784 & 2784 \\
\hline Partial R2 & 0.0593 & 0.052 & 0.0242 & 0.06 & 0.0521 & 0.0248 \\
\hline KP F-Stat & 105.135 & 53.947 & 59.740 & 109.679 & 54.658 & 63.992 \\
\hline KP P-Value & 0.00 & 0.00 & 0.00 & 0.00 & 0.00 & 0.00 \\
\hline Hausman P-Value & 0.83 & 0.81 & 0.94 & 0.87 & 0.97 & 0.72 \\
\hline
\end{tabular}

Notes:

Data from the California Department of Public Health, the California Office of Statewide Health Planning and Development, the U.S. Census, and the National Center for Health Statistics. The dependent variable in all specifications is the log of the number of syphilis diagnoses in a county and month +1 per 100,000 people. Standard errors, shown in parentheses, are clustered at the county level. In addition to the coefficients shown, all models include county, year and month fixed effects. Stars denote statistical significance: * Significant at $10 \%$; ** significant at $5 \%$; *** significant at $1 \%$. 


\section{Table 9}

Fixed Effects Poisson Regression Results of Effects of Methamphetamine Consumption on Syphilis Transmission 1997 to 2000

\begin{tabular}{|c|c|c|c|c|c|c|}
\hline & Total & Males & Females & Total & Males & Females \\
\hline Log Meth Admits Rate & $\begin{array}{c}0.490 \\
(0.50)\end{array}$ & $\begin{array}{c}0.496 \\
(0.58)\end{array}$ & $\begin{array}{l}0.615 \\
(0.49)\end{array}$ & $\begin{array}{l}0.713 \\
(0.44)\end{array}$ & $\begin{array}{l}0.753 \\
(0.50)\end{array}$ & $\begin{array}{c}0.645 \\
(0.47)\end{array}$ \\
\hline Lagged Syphilis Count & & & & $\begin{array}{l}0.011 * * \\
(0.00)\end{array}$ & $\begin{array}{l}0.017 * * \\
(0.01)\end{array}$ & $\begin{array}{l}0.009 \\
(0.01)\end{array}$ \\
\hline Log Alcohol Admits Rate & $\begin{array}{c}0.272 \\
(0.40)\end{array}$ & $\begin{array}{l}0.702 * * \\
(0.36)\end{array}$ & $\begin{array}{l}-0.427 * * \\
(0.19)\end{array}$ & $\begin{array}{l}0.314 \\
(0.41)\end{array}$ & $\begin{array}{l}0.680 * \\
(0.36)\end{array}$ & $\begin{array}{l}-0.436 * * \\
(0.19)\end{array}$ \\
\hline Log Cannabis Admits Rate & $\begin{array}{l}-0.301 * \\
(0.18)\end{array}$ & $\begin{array}{r}-0.052 \\
(0.17)\end{array}$ & $\begin{array}{l}-0.308 * \\
(0.18)\end{array}$ & $\begin{array}{l}-0.411 * * \\
(0.17)\end{array}$ & $\begin{array}{r}-0.134 \\
(0.15)\end{array}$ & $\begin{array}{l}-0.321 * \\
(0.17)\end{array}$ \\
\hline Log Heroin Admits Rate & $\begin{array}{r}-0.085 \\
(0.16)\end{array}$ & $\begin{array}{r}-0.285 \\
(0.19)\end{array}$ & $\begin{array}{l}-0.139 \\
(0.16)\end{array}$ & $\begin{array}{l}-0.108 \\
(0.15)\end{array}$ & $\begin{array}{l}-0.312 * \\
(0.18)\end{array}$ & $\begin{array}{l}-0.149 \\
(0.15)\end{array}$ \\
\hline Log Cocaine Admits Rate & $\begin{array}{l}0.102 \\
(0.17)\end{array}$ & $\begin{array}{l}-0.176 \\
(0.16)\end{array}$ & $\begin{array}{l}0.268 \\
(0.18)\end{array}$ & $\begin{array}{l}0.057 \\
(0.16)\end{array}$ & $\begin{array}{r}-0.235 \\
(0.15)\end{array}$ & $\begin{array}{l}0.264 \\
(0.18)\end{array}$ \\
\hline \% Population Male & $\begin{array}{l}-0.007 \\
(0.60)\end{array}$ & $\begin{array}{l}-0.097 \\
(0.63)\end{array}$ & $\begin{array}{l}0.088 \\
(0.76)\end{array}$ & $\begin{array}{l}0.131 \\
(0.64)\end{array}$ & $\begin{array}{r}-0.051 \\
(0.66)\end{array}$ & $\begin{array}{c}0.146 \\
(0.77)\end{array}$ \\
\hline \% Population Black & $\begin{array}{l}0.670 \\
(0.41)\end{array}$ & $\begin{array}{l}0.383 \\
(0.37)\end{array}$ & $\begin{array}{l}1.024 * \\
(0.58)\end{array}$ & $\begin{array}{l}0.343 \\
(0.32)\end{array}$ & $\begin{array}{l}0.167 \\
(0.33)\end{array}$ & $\begin{array}{c}0.867 \\
(0.54)\end{array}$ \\
\hline \% Population Hispanic & $\begin{array}{l}0.427 \\
(0.34)\end{array}$ & $\begin{array}{l}0.288 \\
(0.33)\end{array}$ & $\begin{array}{l}0.750 * \\
(0.39)\end{array}$ & $\begin{array}{l}0.431 \\
(0.31)\end{array}$ & $\begin{array}{l}0.279 \\
(0.31)\end{array}$ & $\begin{array}{l}0.754 \text { ** } \\
(0.37)\end{array}$ \\
\hline Pop Density in 100s/sq. mile & $\begin{array}{l}0.913^{* * *} \\
(0.26)\end{array}$ & $\begin{array}{l}0.822 \text { *** } \\
(0.24)\end{array}$ & $\begin{array}{l}0.773 * * \\
(0.34)\end{array}$ & $\begin{array}{l}0.808 * * * \\
(0.23)\end{array}$ & $\begin{array}{l}0.729 * * * \\
(0.23)\end{array}$ & $\begin{array}{l}0.743 * * \\
(0.31)\end{array}$ \\
\hline \% Population Age Under 18 & $\begin{array}{l}-2.070 * \\
(1.23)\end{array}$ & $\begin{array}{r}-1.431 \\
(1.18)\end{array}$ & $\begin{array}{l}-2.562 * \\
(1.43)\end{array}$ & $\begin{array}{r}-1.471 \\
(1.13)\end{array}$ & $\begin{array}{r}-1.020 \\
(1.15)\end{array}$ & $\begin{array}{l}-2.303 * \\
(1.34)\end{array}$ \\
\hline \% Population Age 18-39 & $\begin{array}{l}-1.885 * * * \\
(0.65)\end{array}$ & $\begin{array}{l}-1.626 \text { *** } \\
(0.62)\end{array}$ & $\begin{array}{l}-2.405 * * * \\
(0.80)\end{array}$ & $\begin{array}{l}-1.709 * * * \\
(0.57)\end{array}$ & $\begin{array}{l}-1.488 * * \\
(0.59)\end{array}$ & $\begin{array}{l}-2.341 * * * \\
(0.75)\end{array}$ \\
\hline Num & 1872 & 1680 & 1488 & 1872 & 1680 & 1488 \\
\hline
\end{tabular}

\section{Notes:}

Data from the California Department of Public Health, the California Office of Statewide Health Planning and Development, the U.S. Census, and the National Center for Health Statistics. The dependent variable in all specifications is the number of syphilis diagnoses in a county and month. Standard errors, shown in parentheses, are clustered at the county level. In addition to the coefficients shown, all models include the residuals from the first stage regression and county, year and month fixed effects. Stars denote statistical significance: * Significant at $10 \%$; ** significant at 5\%; *** significant at $1 \%$. 